\title{
A merged experimental and theoretical conformational study on alkaline-earth complexes with lariat ethers derived from 4,13-diaza-18-crown-6
}

Israel Carreira-Barral, Aurora Rodríguez-Rodríguez, Martín Regueiro-Figueroa, David Esteban$\underline{\text { Gómez, Carlos Platas-Iglesias, }} \underline{\text { Andrés de Blas }}{ }^{*}, \underline{\text { Teresa Rodríguez-Blas }}{ }^{\dagger}$

Departamento de Química Fundamental, Facultad de Ciencias, Universidade da Coruña, Campus da Zapateira-Rúa da Fraga 10, 15008 A Coruña, Spain

Inorganica Chimica Acta, volume 370, issue 1, pages 270-278, 15 May 2011

Received 21 October 2010, revised 11 January 2011, accepted 21 January 2011, available online 5 February 2011

\section{How to cite:}

I. Carreira-Barral, A. Rodríguez-Rodríguez, M. Regueiro-Figueroa, D. Esteban-Gómez, C. PlatasIglesias, A. De Blas, T. Rodríguez-Blas, A merged experimental and theoretical conformational study on alkaline-earth complexes with lariat ethers derived from 4,13-diaza-18-crown-6, Inorganica Chim. Acta. 370 (2011) 270-278. https://doi.org/10.1016/j.ica.2011.01.070.

\begin{abstract}
Herein, we report the synthesis and structural characterization of alkaline-earth complexes with the bibracchial lariat ethers $N, N^{\prime}$-bis(2-aminobenzyl)-4,13-diaza-18-crown-6 $\left(\mathbf{L}^{2}\right)$ and $N, N^{\prime}$-bis(benzimidazol2ylmethyl)-4,13-diaza-18-crown-6 ( $\left.\mathbf{L}^{4}\right)$. The X-ray crystal structures of the $\mathrm{Ca}$ (II) and $\mathrm{Sr}(\mathrm{II})$ complexes of $\mathbf{L}^{2}$ show the pendant arms of the ligand disposed on opposite sides of the macrocyclic mean plane, which results in an anti conformation in the solid state. A similar anti conformation is also observed for the $\operatorname{Mg}($ II) complex of $\mathbf{L}^{\mathbf{4}}$, whereas the $\mathrm{Ca}(\mathrm{II}), \mathbf{S r}(\mathrm{II})$ and $\mathrm{Ba}(\mathrm{II})$ complexes of $\mathbf{L}^{\mathbf{4}}$ adopt a syn conformation in the solid state, with the two pendant arms pointing at the same side of the crown moiety. However, a different behavior is observed in solution. Indeed, ${ }^{1} \mathrm{H}$ and ${ }^{13} \mathrm{C}$ NMR spectroscopy, in combination with density functional theory (DFT) calculations performed at the B3LYP level, suggests that the $\left[\mathrm{M}\left(\mathbf{L}^{2}\right)\right]^{2+}$ and $\left[\mathrm{M}\left(\mathbf{L}^{4}\right)\right]^{2+}(\mathrm{M}=\mathrm{Ca}, \mathrm{Sr}$ or Ba) complexes exist in solution as a mixture of syn and anti isomers involved in a dynamic equilibrium. Our results also show that the relative abundance of the syn conformation increases as the ionic radius of the metal ion increases and, furthermore, for a given metal ion the proportion of syn isomer is always higher for $\mathbf{L}^{4}$ complexes than for $\mathbf{L}^{2}$ ones.
\end{abstract}

Keywords: macrocyclic ligands; crystal structures; crown ethers; alkaline-earth complexes

\footnotetext{
*andres.blas@udc.es

$\dagger$ teresa.rodriguez.blas@udc.es
} 


\section{Introduction}

The macrocyclic framework of crown and aza-crown ethers has proven to be a very useful platform for the selective complexation of hard cations such as alkaline and alkaline earth metal ions ${ }^{[1-4]}$. Furthermore, crown ethers can be functionalized with different side chains containing additional donor atoms that allow to enhance the cation binding affinity and selectivity of the receptor in comparison to the parent macrocycle ${ }^{[5]}$. Due to their interesting coordination properties, crown ethers and their derivatives have found many applications in different areas, i.e., separation and transport processes for the recovery or removal of metal ions ${ }^{[6]}$, preparation of ion-selective electrodes ${ }^{[7,8]}$ and stationary phases in chromatographic techniques ${ }^{[9]}$, the design of chromogenic or fluorogenic chemosensors ${ }^{[10-12]}$, or phase-transfer catalysis in organic reactions ${ }^{[13,14]}$. In addition to their versatility and broad use in chemistry and industry, it has been also suggested that crown ethers may find application as novel anticancer drugs ${ }^{[15]}$. Due to their properties as ionophores, crown ethers have also considerable biochemical relevance as models of natural ionophores such as valinomycin ${ }^{[16]}$.

The bibracchial lariat ethers $\mathbf{L}^{\mathbf{1}}-\mathbf{L}^{\mathbf{4}}$ shown in Scheme 1, which contain aniline or benzimidazole pendants, have revealed as very versatile receptors. We have carried out studies to asses their different complexation capabilities towards post-transitional divalent metal ions such as $\mathrm{Zn}(\mathrm{II})^{[17]}, \mathrm{Pb}$ (II) and $\mathrm{Cd}(\mathrm{II})^{[18-21]}$ as well as transition metal ions. With first-row transition metal ions such as $\mathrm{Ni}(\mathrm{II}), \mathrm{Co}$ (II) and $\mathrm{Cu}$ (II), $\mathbf{L}^{2}$ and $\mathbf{L}^{4}$ are able to form binuclear complexes ${ }^{[22,23]}$, whereas the related receptors $\mathbf{L}^{\mathbf{1}}$ and $\mathbf{L}^{\mathbf{3}}$ only form mononuclear complexes ${ }^{[24-26]}$. Interestingly, these mononuclear complexes represent unusual examples of structurally characterized seven coordinate (pentagonal bipyramidal) complexes of first-row transition metal ions.

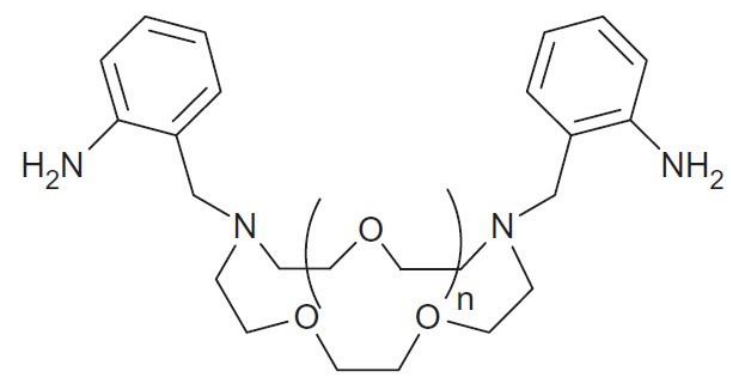

$$
\begin{aligned}
& \mathrm{L}^{1}: \mathrm{n}=1 \\
& \mathrm{~L}^{2}: \mathrm{n}=2
\end{aligned}
$$

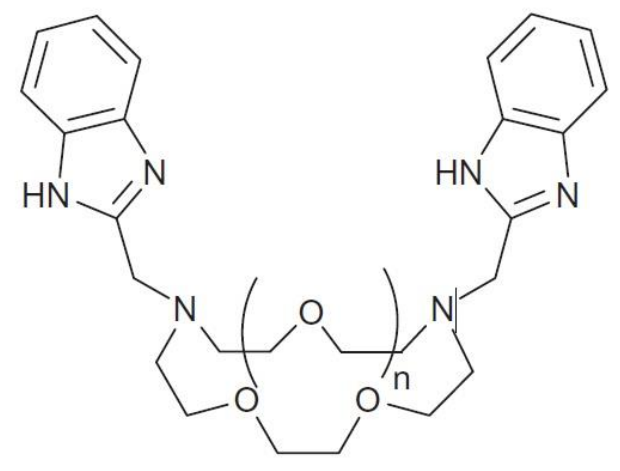

$$
\begin{aligned}
& \mathrm{L}^{3}: \mathrm{n}=1 \\
& \mathrm{~L}^{4}: \mathrm{n}=2
\end{aligned}
$$

Scheme 1.

We have previously reported that reaction of $\mathbf{L}^{1}$ and $\mathbf{L}^{2}$ with dialdehydes leads to the formation of lateral macrobicyclic structures that are useful for the coordination of both cations and anions ${ }^{[27-29]}$. We have found that these macrobicycles cannot be prepared by direct reaction between the organic precursors due to the anti arrangement adopted by the diamines $\mathbf{L}^{1}$ and $\mathbf{L}^{2}$, but Ba(II) can act as an effective template, thereby facilitating the formation of the desired macrobicycles in high yields ${ }^{[30]}$. The effectiveness of $\mathrm{Ba}$ (II) to template such macrobicycles comes from its ability to arrange the pendant arms of $\mathbf{L}^{1}$ and $\mathbf{L}^{2}$ in a syn conformation. Although $\left[\mathrm{Ba}\left(\mathbf{L}^{1}\right)\right]^{2+}$ complex adopts the expected syn conformation both in the solid state and solution, surprisingly $\left[\mathrm{Ba}\left(\mathbf{L}^{2}\right)\right]^{2+}$ presents an antiarrangement in the solid state. In solution, 
however, it exists as a mixture of syn and anti isomers ${ }^{[31]}$. As a continuation of these works, herein we report a structural study both in the solid state and solution of alkaline-earth complexes with receptors $\mathbf{L}^{2}$ and $\mathbf{L}^{4}$.

\section{Experimental}

\subsection{Reagents}

$N, N^{\prime}$-bis(2-aminobenzyl)-4,13-diaza-18-crown-6 ( $\left.\mathbf{L}^{2}\right)$ and $N, N^{\prime}$-bis(benzimidazol-2ylmethyl)-4,13-diaza-18crown-6 $\left(\mathbf{L}^{4}\right)$ were prepared according to the literature methods ${ }^{[25,32]}$. All other chemicals were purchased from commercial sources and used without further purification. Solvents were of reagent grade purified by the usual methods. Caution! Although, we have experienced no difficulties with the perchlorate salts, these should be regarded as potentially explosive and handled with care ${ }^{[33]}$.

\subsection{Synthesis}

\subsection{1. $\left[\mathrm{Ca}\left(\boldsymbol{L}^{2}\right)\right]\left(\mathrm{ClO}_{4}\right)_{2} \cdot 0.5 \mathrm{Et}_{2} \mathrm{O}(\mathbf{1 a})$}

$0.099 \mathrm{~g}$ of $\mathrm{Ca}\left(\mathrm{ClO}_{4}\right)_{2} \cdot 4 \mathrm{H}_{2} \mathrm{O}(0.318 \mathrm{mmol})$ were added to a solution of $\mathbf{L}^{2}(0.150 \mathrm{~g}, 0.318 \mathrm{mmol})$ in ethanol $(10 \mathrm{~mL})$. The resulting mixture was refluxed for $24 \mathrm{~h}$. The white precipitate formed was isolated by filtration, washed with diethyl ether and air-dried. Yield: $0.187 \mathrm{~g}(79 \%)$. Anal. Calc. for $\mathrm{C}_{28} \mathrm{H}_{45} \mathrm{CaCl}_{2} \mathrm{~N}_{4} \mathrm{O}_{12.5}$ : C, 44.9; H, 6.1; N, 7.5. Found: C, 44.7; H, 5.9; N, 7.6\%. FAB-MS: $m / z(\% \mathrm{BPI}): 611(14)\left[\mathrm{Ca}\left(\mathrm{L}^{2}\right)\left(\mathrm{ClO}_{4}\right)\right]^{+}$, $511(10) \quad\left[\mathrm{Ca}\left(\mathbf{L}^{2}-\mathrm{H}\right)\right]^{+} . \quad$ IR $\quad\left(\mathrm{cm}^{-1}\right): \quad 3332, \quad 3287 \quad\left(v_{\mathrm{N}-\mathrm{H}}\right), \quad 1614 \quad\left(\delta_{\mathrm{N}-\mathrm{H}}\right), \quad 1073 \quad\left(v_{\mathrm{Cl}-\mathrm{O}}\right), \quad 619 \quad\left(\delta_{\mathrm{Cl}-\mathrm{O}}\right)$. $\Lambda_{\mathrm{M}}\left(\mathrm{cm}^{2} \Omega^{-1} \mathrm{~mol}^{-1}\right): 220$. Single crystals of formula $\left[\mathrm{Ca}\left(\mathbf{L}^{2}\right)\right]\left(\mathrm{ClO}_{4}\right)_{2}(\mathbf{1 b})$ suitable for single crystal X-ray diffraction analysis were obtained by slow diffusion of diethyl ether into a solution of the complex in methanol.

\subsection{2. $\left[\mathrm{Sr}\left(\boldsymbol{L}^{2}\right)\right]\left(\mathrm{ClO}_{4}\right)_{2}(2)$}

The preparation of this compound, which was isolated as a white powder, followed the same procedure described for 1a by using a solution of $\operatorname{Sr}\left(\mathrm{ClO}_{4}\right)_{2}(0.091 \mathrm{~g}, 0.318 \mathrm{mmol})$. Yield: $0.198 \mathrm{~g}(82 \%)$. Anal. Calc. for $\mathrm{C}_{26} \mathrm{H}_{40} \mathrm{Cl}_{2} \mathrm{~N}_{4} \mathrm{O}_{12} \mathrm{Sr}$ : C, 41.1; H, 5.3; N, 7.4. Found: C, 40.9; H, 5.5; N, 7.0\%. FAB-MS: $\mathrm{m} / z$ (\%BPI): 659(30) $\left[\mathrm{Sr}\left(\mathbf{L}^{2}\right)\left(\mathrm{ClO}_{4}\right)\right]^{+}, 559(7)\left[\mathrm{Sr}\left(\mathbf{L}^{2}-\mathrm{H}\right)\right]^{+} . \mathrm{IR}\left(\mathrm{cm}^{-1}\right): 3349,3284\left(v_{\mathrm{N}-\mathrm{H}}\right), 1616\left(\delta_{\mathrm{N}-\mathrm{H}}\right), 1063\left(v_{\mathrm{Cl}-\mathrm{O}}\right), 622$ $\left(\delta_{\mathrm{Cl}-\mathrm{O}}\right) . \Lambda_{\mathrm{M}}\left(\mathrm{cm}^{2} \Omega^{-1} \mathrm{~mol}^{-1}\right)$ : 301 . Single crystals of formula 2 suitable for single crystal X-ray diffraction analysis were obtained by slow diffusion of diethyl ether into a solution of the complex in methanol.

\subsection{3. $\left[\mathrm{Mg}\left(\boldsymbol{L}^{4}\right)\right]\left(\mathrm{ClO}_{4}\right)_{2} \cdot 5 \mathrm{H}_{2} \mathrm{O}(3 \boldsymbol{a})$}

A solution of $\mathrm{Mg}\left(\mathrm{ClO}_{4}\right)_{2}(0.048 \mathrm{~g}, 0.214 \mathrm{mmol})$ in ethanol $(5 \mathrm{~mL})$ was added to a stirred solution of $\mathbf{L}^{4}(0.100 \mathrm{~g}, 0.192 \mathrm{mmol})$ in the same solvent $(20 \mathrm{~mL})$. The mixture was refluxed for $24 \mathrm{~h}$, and the resultant yellow solution allowed to evaporate slowly at room temperature. The pale brown precipitate

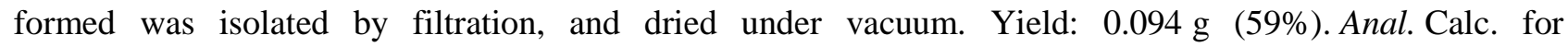
$\mathrm{C}_{28} \mathrm{H}_{48} \mathrm{Cl}_{2} \mathrm{MgN}_{6} \mathrm{O}_{17}: \mathrm{C}, 40.2 ; \mathrm{H}, 5.8 ; \mathrm{N}, 10.05$. Found: $\mathrm{C}, 40.4 ; \mathrm{H}, 5.2 ; \mathrm{N}, 10.2 \%$. FAB-MS: $\mathrm{m} / z$ (\%BPI): 645(9) $\left[\mathrm{Mg}\left(\mathbf{L}^{4}\right)\left(\mathrm{ClO}_{4}\right)\right]^{+}, 545(21)\left[\mathrm{Mg}\left(\mathbf{L}^{4}-\mathrm{H}\right)\right]^{+} . \mathrm{IR}\left(\mathrm{cm}^{-1}\right): 1625\left(v_{\mathrm{C}}=\mathrm{N}\right), 1539\left(v_{\mathrm{C}}=\mathrm{C}\right), 1078\left(v_{\mathrm{Cl}-\mathrm{O}}\right), 620$ $\left(\delta_{\mathrm{Cl}-\mathrm{O}}\right) . \Lambda_{\mathrm{M}}\left(\mathrm{cm}^{2} \Omega^{-1} \mathrm{~mol}^{-1}\right): 302$. Colorless single crystals of formula $\left[\mathrm{Mg}\left(\mathbf{L}^{4}\right)\right]\left(\mathrm{ClO}_{4}\right)_{2} \cdot 2 \mathrm{H}_{2} \mathrm{O}(\mathbf{3 b})$ suitable for single crystal X-ray diffraction analysis were obtained by slow diffusion of diethyl ether into a solution of the complex in acetonitrile.

\subsection{4. $\left[\mathrm{Ca}\left(\boldsymbol{L}^{4}\right)\right]\left(\mathrm{ClO}_{4}\right)_{2} \cdot \mathrm{H}_{2} \mathrm{O}(\mathbf{4 a})$}

A solution of $\mathrm{Ca}\left(\mathrm{ClO}_{4}\right)_{2} \cdot 4 \mathrm{H}_{2} \mathrm{O}(0.067 \mathrm{~g}, 0.216 \mathrm{mmol})$ in ethanol $(5 \mathrm{~mL})$ was added to a stirred solution of $\mathbf{L}^{4}(0.100 \mathrm{~g}, 0.192 \mathrm{mmol})$ in the same solvent $(20 \mathrm{~mL})$, and the resulting mixture was refluxed for $24 \mathrm{~h}$. 
The white precipitate formed was isolated by filtration, and dried under vacuum. Yield: $0.101 \mathrm{~g}$ (68\%). Anal. Calc. for $\mathrm{C}_{28} \mathrm{H}_{40} \mathrm{CaCl}_{2} \mathrm{CaN}_{6} \mathrm{O}_{13}: \mathrm{C}, 43.1 ; \mathrm{H}, 5.2 ; \mathrm{N}, 10.8$. Found: C, 43.35; H, 4.95; N, $11.2 \%$. FAB-MS: $m / z$ (\%BPI): 661(49) $\left[\mathrm{Ca}\left(\mathbf{L}^{4}\right)\left(\mathrm{ClO}_{4}\right)\right]^{+}, 561(61)\left[\mathrm{Ca}\left(\mathbf{L}^{4}-\mathrm{H}\right)\right]^{+} . \mathrm{IR}\left(\mathrm{cm}^{-1}\right): 1624\left(v_{\mathrm{C}}=\mathrm{N}\right), 1538\left(v_{\mathrm{C}}\right.$ $=\mathrm{C}), 1099\left(v_{\mathrm{Cl}-\mathrm{O}}\right), 620\left(\delta_{\mathrm{Cl}-\mathrm{O}}\right) . \Lambda_{\mathrm{M}}\left(\mathrm{cm}^{2} \Omega^{-1} \mathrm{~mol}^{-1}\right)$ : 292. Pale yellow single crystals of formula $\left[\mathrm{Ca}\left(\mathbf{L}^{4}\right)\right]\left(\mathrm{ClO}_{4}\right)_{2} \cdot 1.5 \mathrm{H}_{2} \mathrm{O}(\mathbf{4 b})$ suitable for single crystal X-ray diffraction analysis were obtained by slow evaporation of the mother liquor.

\subsection{5. $\left[\mathrm{Sr}\left(\boldsymbol{L}^{4}\right)\right]\left(\mathrm{ClO}_{4}\right)_{2} \cdot \mathrm{EtOH} \cdot \mathrm{H}_{2} \mathrm{O}(\mathbf{5 a})$}

The preparation of this compound, which was isolated as a white powder, followed the same procedure described for $4 \mathbf{a}$ by using a solution of $\operatorname{Sr}\left(\mathrm{ClO}_{4}\right)_{2}(0.062 \mathrm{~g}, 0.215 \mathrm{mmol})$. Yield: $0.105 \mathrm{~g}(63 \%)$. Anal. Calc. for $\mathrm{C}_{30} \mathrm{H}_{46} \mathrm{Cl}_{2} \mathrm{~N}_{6} \mathrm{O}_{14} \mathrm{Sr}$ : C, 41.3; H, 5.3; N, 9.6. Found: C, 41.2; H, 5.0; N, 10.1\%. FAB-MS: $m / z$ (\%BPI): 709(100) [Sr( $\left.\left.\mathbf{L}^{4}\right)\left(\mathrm{ClO}_{4}\right)\right]^{+}, 609(48)\left[\mathrm{Sr}\left(\mathbf{L}^{4}-\mathrm{H}\right)\right]^{+} . \mathrm{IR}\left(\mathrm{cm}^{-1}\right): 1625\left(v_{\mathrm{C}}=\mathrm{N}\right), 1537\left(v_{\mathrm{C}}=\mathrm{C}\right), 1090\left(v_{\mathrm{Cl}-\mathrm{O}}\right), 621$ $\left(\delta_{\mathrm{Cl}-\mathrm{O}}\right) . \Lambda_{\mathrm{M}}\left(\mathrm{cm}^{2} \Omega^{-1} \mathrm{~mol}^{-1}\right): 296$. Colorless single crystals of formula $\left[\mathrm{Sr}\left(\mathbf{L}^{4}\right)\right]\left(\mathrm{ClO}_{4}\right)_{2} \cdot 0.36 \cdot \mathrm{H}_{2} \mathrm{O} \cdot 0.64 \mathrm{MeOH}$ (5b) suitable for single crystal X-ray diffraction analysis were obtained by slow diffusion of diethyl ether into a solution of the complex in methanol.

\subsection{6. $\left[\mathrm{Ba}\left(\mathbf{L}^{4}\right)\right]\left(\mathrm{ClO}_{4}\right)_{2}(\mathbf{6})$}

The preparation of this compound, which was isolated as a pale brown powder, followed the same procedure described for $\mathbf{4 a}$ by using a solution of $\mathrm{Ba}\left(\mathrm{ClO}_{4}\right)_{2} \cdot 3 \mathrm{H}_{2} \mathrm{O} \quad(0.083 \mathrm{~g}, 0.212 \mathrm{mmol})$. Yield: $0.127 \mathrm{~g}$ (77\%). Anal. Calc. for $\mathrm{C}_{28} \mathrm{H}_{38} \mathrm{BaCl}_{2} \mathrm{~N}_{6} \mathrm{O}_{12}: \mathrm{C}, 39.2 ; \mathrm{H}, 4.5$; N, 9.8. Found: C, 38.6; H, 4.5; N, 9.6\%. FABMS: $m / z$ (\%BPI): 759(58) $\left[\mathrm{Ba}\left(\mathbf{L}^{4}\right)\left(\mathrm{ClO}_{4}\right)\right]^{+}, 659(35)\left[\mathrm{Ba}\left(\mathbf{L}^{4}-\mathrm{H}\right)\right]^{+} . \mathrm{IR}\left(\mathrm{cm}^{-1}\right): 1615\left(v_{\mathrm{C}}=\mathrm{N}\right), 1538\left(v_{\mathrm{C}}=\mathrm{C}\right)$, $1088\left(v_{\mathrm{Cl}-\mathrm{O}}\right), 622\left(\delta_{\mathrm{Cl}-\mathrm{O}}\right) . \Lambda_{\mathrm{M}}\left(\mathrm{cm}^{2} \Omega^{-1} \mathrm{~mol}^{-1}\right): 294$. Pale yellow single crystals of $\mathbf{6}$ suitable for single crystal $\mathrm{X}$-ray diffraction analysis were obtained by slow evaporation of the mother liquor.

\subsection{Measurements}

Elemental analyses were carried out on a Carlo Erba 1108 elemental analyzer. FAB mass spectra were recorded on a Fisons Quatro mass spectrometer with a Cs ion gun using 3-nitrobenzyl alcohol as matrix. ${ }^{1} \mathrm{H}$ and ${ }^{13} \mathrm{C}$ NMR spectra were run on a Bruker Advance 500 instrument using acetonitrile- $d_{3}$ as solvent. IR spectra were recorded using a Bruker Vector 22 spectrophotometer equipped with a Golden Gate Attenuated Total Reflectance (ATR) accessory (Specac). Conductivity measurements were carried out with a Crison Micro CM 2201 conductivimeter using $c a .10^{-3} \mathrm{M}$ solutions of the complexes in acetonitrile.

\subsection{X-ray crystallography}

Three-dimensional X-ray data were collected on Bruker SMART 1000 CCD (compounds 1b and 2), BrukerNonius X8 Apex-Kappa CCD (3b and $\mathbf{5 b}$ ) or Bruker X8 APEXII CCD diffractometers (4b and $\mathbf{6})$ by the omega and phi scan method. Reflections were measured from a hemisphere of data collected of frames each covering $0.5^{\circ}$ in omega. The reflections measured were corrected for Lorentz and polarization effects and for absorption by semi-empirical methods based on symmetry-equivalent and repeated reflections. The solution, refinement and analysis of the single crystal X-ray diffraction data was performed with WinGX suite for small molecule single-crystal crystallography ${ }^{[34]}$. The structures were solved by Patterson methods with dirdif99 ${ }^{[35]}(\mathbf{3 b}, \mathbf{4 b}$ and $\mathbf{6})$, or direct methods with shelxs-97 ${ }^{[36]}$ (1) and $\left.\mathbf{2}\right)$ or superflip ${ }^{[37]}$ (5b), and refined by full-matrix least-squares methods on $F^{2}$ with shelx197 ${ }^{[36]}$. The hydrogen atoms were included in calculated positions and refined by using a riding mode. For compound $\mathbf{5 b}$ one of the coordination positions of $\mathrm{Sr}$ was occupied alternatively by a methanol molecule (occupation factor $0.642(4)$ ) or by a water molecule (occupation factor 0.358(4)), but the second hydrogen atom of the water molecule was not found due to the very small electron density. Refinement converged with allowance for thermal anisotropy of all nonhydrogen atoms in every case. Crystal data and details on data collection and refinement are summarized in Table 1, Table 2. 
Table 1. Crystal data and structure refinement for $\mathbf{1 b}$ and $\mathbf{2}$.

\begin{tabular}{|c|c|c|}
\hline & $1 b$ & 2 \\
\hline Empirical formula & $\mathrm{C}_{26} \mathrm{H}_{40} \mathrm{CaCl}_{2} \mathrm{~N}_{4} \mathrm{O}_{12}$ & $\mathrm{C}_{26} \mathrm{H}_{40} \mathrm{Cl}_{2} \mathrm{~N}_{4} \mathrm{O}_{12} \mathrm{Sr}$ \\
\hline Formula weight & 711.60 & 759.14 \\
\hline$T(\mathrm{~K})$ & $298(2)$ & $293.0(2)$ \\
\hline$\lambda(\AA)$ & 0.71073 & 0.71073 \\
\hline Crystal system & orthorhombic & triclinic \\
\hline Space group & Fdd 2 & $\mathrm{P} 1^{-}$ \\
\hline$a(\AA)$ & $19.4127(14)$ & $10.4567(5)$ \\
\hline$b(\AA)$ & $30.140(2)$ & $10.4988(5)$ \\
\hline$c(\AA)$ & $10.9696(8)$ & $17.0549(8)$ \\
\hline$\alpha\left(^{\circ}\right)$ & 90 & $98.003(1)$ \\
\hline$\beta\left(^{\circ}\right)$ & 90 & $95.411(1)$ \\
\hline$\gamma\left({ }^{\circ}\right)$ & 90 & 119.294(1) \\
\hline$V\left(\AA^{3}\right)$ & $6418.3(8)$ & $1588.14(13)$ \\
\hline$F\left(\begin{array}{lll}0 & 0 & 0\end{array}\right)$ & 2992 & 784 \\
\hline$Z$ & 8 & 2 \\
\hline$\rho\left(\mathrm{g} \mathrm{cm}^{-3}\right)$ & 1.473 & 1.587 \\
\hline$\mu\left(\mathrm{mm}^{-1}\right)$ & 0.429 & 1.933 \\
\hline$\theta\left(^{\circ}\right)$ & $2.24-28.31$ & $2.25-28.30$ \\
\hline Independent reflections $\left(R_{\text {int }}\right)$ & 0.0785 & 0.0171 \\
\hline Reflections measured & 10194 & 11007 \\
\hline Reflections observed & 1685 & 6531 \\
\hline Goodness of fit (GOF) on $F^{2}$ & 0.989 & 1.028 \\
\hline$R_{1}^{a}$ & 0.0468 & 0.0417 \\
\hline$w R_{2}(\text { all data })^{b}$ & 0.1095 & 0.1114 \\
\hline $\begin{array}{l}\text { Residual electron density } \\
\text { (maximum/minimum) }\left(\mathrm{e} \AA^{-3}\right)\end{array}$ & 0.232 and -0.634 & 1.183 and -0.471 \\
\hline
\end{tabular}

${ }^{a} R_{1}=\Sigma\left\|F_{0}\left|-F_{c} \| / \Sigma\right| F_{0} \mid\right.$.

${ }^{b} w R_{2}=\left\{\Sigma\left[w\left(\|\left. F_{0}\right|^{2}-\left|F_{c}\right|^{2} \mid\right)^{2}\right] \mid / \Sigma\left[w\left(F_{0}^{4}\right)\right]\right\}^{1 / 2}$

\subsection{DFT calculations}

All calculations were performed employing hybrid DFT with the B3LYP exchange-correlation functional ${ }^{[38,39]}$, and the gaussian 03 package (Revision C.01) ${ }^{[40]}$. Full geometry optimizations of the $\left[\mathrm{M}\left(\mathbf{L}^{2}\right)\right]^{2+}(\mathrm{M}=\mathrm{Ca}, \mathrm{Sr})$ and $\left[\mathrm{M}\left(\mathbf{L}^{4}\right)\right]^{2+}(\mathrm{M}=\mathrm{Ca}, \mathrm{Sr}$ or $\mathrm{Ba})$ systems were performed in vacuo by using the standard 6-31G(d) basis set for the ligand atoms and the LANL2DZ valence and effective core potential functions for the metals ${ }^{[41-43]}$. The default values for the integration grid ("fine") and the SCF energy convergence criteria $\left(10^{-6}\right)$ were used. The stationary points found on the potential energy surfaces as a result of the geometry optimizations have been tested to represent energy minima rather than saddle points via frequency analysis. The relative free energies of the different conformations calculated for each system include non-potential-energy contributions (that is, zero point energy and thermal terms) obtained by frequency analysis. 
Table 2. Crystal data and structure refinement for $\mathbf{3 b}, \mathbf{4 b}, \mathbf{5 b}$ and $\mathbf{6}$.

\begin{tabular}{|c|c|c|c|c|}
\hline & $3 b$ & $4 b$ & $5 \mathbf{b}$ & 6 \\
\hline Empirical formula & $\mathrm{C}_{28} \mathrm{H}_{42} \mathrm{Cl}_{2} \mathrm{MgN}_{6} \mathrm{O}_{14}$ & $\mathrm{C}_{56} \mathrm{H}_{82} \mathrm{Ca}_{2} \mathrm{Cl}_{4} \mathrm{~N}_{12} \mathrm{O}_{27}$ & $\mathrm{C}_{28.5} \mathrm{H}_{40.5} \mathrm{Cl}_{2} \mathrm{~N}_{6} \mathrm{O}_{13} \mathrm{Sr}$ & $\mathrm{C}_{28} \mathrm{H}_{38} \mathrm{BaCl}_{2} \mathrm{~N}_{6} \mathrm{O}_{12}$ \\
\hline Molecular weight & 781.89 & 1577.30 & 833.69 & 858.88 \\
\hline$T(\mathrm{~K})$ & $100.0(2)$ & $100.0(2)$ & $100.0(2)$ & $100.0(2)$ \\
\hline$\lambda(\AA)$ & 0.71073 & 0.71073 & 0.71073 & 0.71073 \\
\hline Crystal system & monoclinic & monoclinic & monoclinic & monoclinic \\
\hline Space group & $P 2(1) / \mathrm{n}$ & $C 2 / \mathrm{c}$ & $P 2(1)$ & $P 1(2) 1 / c(1)$ \\
\hline$a(\AA)$ & $17.0195(11)$ & $11.2147(11)$ & $10.4633(7)$ & $11.1641(4)$ \\
\hline$b(\AA)$ & $11.2984(8)$ & $17.8848(18)$ & $17.731(1)$ & $17.7565(6)$ \\
\hline$c(\AA)$ & $20.0913(14)$ & $17.5781(15)$ & $10.9006(7)$ & $33.9236(10)$ \\
\hline$\alpha\left(^{\circ}\right)$ & 90 & 90 & 90 & 90 \\
\hline$\beta\left(^{\circ}\right)$ & $113.993(3)$ & $91.081(4)$ & $117.638(4)$ & $94.039(2)$ \\
\hline$\gamma\left({ }^{\circ}\right)$ & 90 & 90 & 90 & 90 \\
\hline$V\left(\AA^{3}\right)$ & $3529.6(4)$ & $3525.1(6)$ & $1791.5(2)$ & $6708.2(4)$ \\
\hline$F\left(\begin{array}{lll}0 & 0 & 0\end{array}\right)$ & 1640 & 1652 & 859 & 3472 \\
\hline$Z$ & 4 & 2 & 2 & 8 \\
\hline$\rho\left(\mathrm{g} \mathrm{cm}^{-3}\right)$ & 1.471 & 1.486 & 1.545 & 1.701 \\
\hline$\mu\left(\mathrm{mm}^{-1}\right)$ & 0.277 & 0.403 & 1.725 & 1.414 \\
\hline$\theta\left(^{\circ}\right)$ & $2.12-28.35$ & $2.14-23.29$ & $2.30-25.07$ & $2.29-28.34$ \\
\hline Independent reflections $\left(R_{\text {int }}\right)$ & 0.0526 & 0.1251 & 0.0849 & 0.0865 \\
\hline Reflections measured & 35259 & 26896 & 39314 & 67680 \\
\hline Reflections observed & 5643 & 1609 & 5374 & 10110 \\
\hline Goodness of fit (GOF) on $F^{2}$ & 1.061 & 1.019 & 1.085 & 1.004 \\
\hline$R_{1}^{a}$ & 0.0718 & 0.0600 & 0.0455 & 0.0541 \\
\hline$w R_{2}$ (all data) ${ }^{b}$ & 0.2030 & 0.1468 & 0.1076 & 0.1289 \\
\hline $\begin{array}{l}\text { Largest differences peak and } \\
\text { hole }\left(\mathrm{e} \AA^{-3}\right)\end{array}$ & 1.317 and -0.667 & 0.369 and -0.422 & 1.047 and -0.322 & 2.425 and -1.422 \\
\hline
\end{tabular}

${ }^{a} R_{1}=\Sigma\left\|F_{0}\left|-F_{c} \| / \Sigma\right| F_{0} \mid\right.$.

${ }^{b} w R_{2}=\left\{\Sigma\left[w\left(\|\left. F_{0}\right|^{2}-\left|F_{c}\right|^{2} \mid\right)^{2}\right] \mid / \Sigma\left[w\left(F_{0}^{4}\right)\right]\right\}^{1 / 2}$.

\section{Results and discussion}

\subsection{Synthesis and characterization}

Complexes of formula $\left[\mathrm{M}\left(\mathbf{L}^{2}\right)\right]\left(\mathrm{ClO}_{4}\right)_{2} \cdot x \mathrm{Et}_{2} \mathrm{O}(\mathrm{M}=\mathrm{Ca}$ or $\mathrm{Sr})$ and $\left[\mathrm{M}\left(\mathbf{L}^{4}\right)\right]\left(\mathrm{ClO}_{4}\right)_{2} \cdot x \mathrm{EtOH} \cdot y \mathrm{H}_{2} \mathrm{O}(\mathrm{M}=\mathrm{Mg}$, $\mathrm{Ca}, \mathrm{Sr}$ or $\mathrm{Ba}$ ) were prepared by reaction of $\mathbf{L}^{2}$ or $\mathbf{L}^{4}$ with the corresponding metal perchlorate in ethanol under the conditions described in Section 2. Attempts to isolate the corresponding $\mathrm{Mg}$ (II) complex with $\mathbf{L}^{2}$ were unsuccessful. The $\left[\mathrm{Ba}\left(\mathbf{L}^{2}\right)\right]\left(\mathrm{ClO}_{4}\right)_{2}$ complex was previously prepared by us and its solid state and solution structure reported ${ }^{[30,31]}$.

The FAB-MS show peaks due to the $\left[\mathrm{M}\left(\mathrm{L}^{n}\right)\left(\mathrm{ClO}_{4}\right)\right]^{+}$and $\left[\mathrm{M}\left(\mathrm{L}^{n}-\mathrm{H}\right)\right]^{+}(n=2$ or 4$)$ entities, which confirms the formation of the expected complexes. The IR spectra of $\mathbf{L}^{2}$ complexes display bands at ca. 3340 and $3280 \mathrm{~cm}^{-1}$, respectively corresponding to the $v_{\mathrm{as}}\left(\mathrm{NH}_{2}\right)$ and $v_{\mathrm{s}}\left(\mathrm{NH}_{2}\right)$ stretching modes of the coordinated amine groups, whereas the IR spectra of $\mathbf{L}^{4}$ complexes show a band at $c a .1538 \mathrm{~cm}^{-1}$ due to the $v(\mathrm{C}=\mathrm{C})$ stretching frequency of the benzimidazole groups ${ }^{[20]}$. This band is shifted by $\sim 15 \mathrm{~cm}^{-1}$ to higher wavenumbers with respect to its position in the spectrum of the free ligand, in line with the coordination of 
the pendant arms to the corresponding metal ion. In all cases, bands corresponding to the $v_{\text {as }}(\mathrm{ClO})$ stretching and $\delta_{\text {as }}(\mathrm{OClO})$ bending modes of the perchlorate groups are observed at ca. $1090-1070$ and $620 \mathrm{~cm}^{-1}$, respectively ${ }^{[44]}$. The molar conductivity values, as measured in $\sim 10^{-3} \mathrm{M}$ acetonitrile solutions of the complexes, fall in the range generally accepted for 2:1 electrolytes in this solvent $\left(220-300 \mathrm{~cm}^{2} \Omega^{-1} \mathrm{~mol}^{-1}\right)$, suggesting that the perchlorate anions are not coordinated to the metal ion in solution ${ }^{[45]}$.

\subsection{Solid state structure}

The solid state structures of the six reported compounds were determined by single crystal X-ray diffraction analyses. Compound $\mathbf{1 b}$ crystallizes in the orthorhombic Fdd2 space group, and the asymmetric unit comprises a half molecule. Crystals contain the $\left[\mathrm{Ca}\left(\mathbf{L}^{2}\right)\right]^{2+}$ complex cation and two perchlorate anions involved in hydrogen-bonding interaction with the $-\mathrm{NH}_{2}$ groups. A view of the structure of the complex is shown in Fig. 1, while bond distances of the metal coordination environment are shown in Table 3. Compound 2 crystallizes in the triclinic space group $\mathrm{P}^{-}$, and crystals contain the $\left[\operatorname{Sr}\left(\mathbf{L}^{2}\right)\left(\mathrm{ClO}_{4}\right)\right]^{+}$entity and a non-coordinating perchlorate anion. Both the coordinating and non-coordinating perchlorate anions are involved in hydrogen bonding interactions with the $-\mathrm{NH}_{2}$ groups of the ligand. A view of the structure of the complex is shown in Fig. 2, while bond distances of the metal coordination environment are shown in Table 3. In both $\left[\mathrm{Ca}\left(\mathbf{L}^{2}\right)\right]^{2+}$ and $\left[\operatorname{Sr}\left(\mathbf{L}^{2}\right)\left(\mathrm{ClO}_{4}\right)\right]^{+}$complexes the metal ion is directly bound to the eight available donor atoms of the ligand. In the $\mathrm{Sr}$ (II) complex, an oxygen atom of a monodentate perchlorate group completes the coordination sphere, which results in a nine-coordinate complex. The distances between the metal ions and the tertiary amine nitrogen atoms are considerably longer than those to the nitrogen atoms of the pendant arms. The oxygen atoms of the crown moiety provide the strongest interaction of the ligand to the metal ion, as expected due to the classification the metal ions are hard in the Pearson HSAB ${ }^{[46]}$. The distances between the metal ions and the donor atoms of the crown moiety are very similar to those observed for eight-coordinate $\mathrm{Ca}(\mathrm{II}){ }^{[47-49]}$ and nine-coordinate $\mathrm{Sr}$ (II) complexes ${ }^{[50]}$ with ligands derived from 4,13diaza-18-crown-6. As previously observed for the $\left[\mathrm{Ba}\left(\mathbf{L}^{2}\right)\left(\mathrm{ClO}_{4}\right)\right]^{+}$complex ${ }^{[31]}$, in the $\left[\mathrm{Ca}\left(\mathbf{L}^{2}\right)\right]^{2+}$ and $\left[\mathrm{Sr}\left(\mathbf{L}^{2}\right)\left(\mathrm{ClO}_{4}\right)\right]^{+}$complexes the pendant arms of the ligand are pointing to opposite sides of the macrocyclic mean plane, resulting an anti conformation. In $\left[\mathrm{Ca}\left(\mathbf{L}^{2}\right)\right]^{2+}$ the two aniline pendant arms are folded towards the macrocyclic fragment containing $\mathrm{O}(1)$, the mean planes described by the aromatic units intersecting at $69.15^{\circ}$. As a consequence, the $\left[\mathrm{Ca}\left(\mathbf{L}^{2}\right)\right]^{2+}$ possesses an undistorted $C_{2}$ symmetry in the solid state, where the $C_{2}$ axis passes through the $\mathrm{O}-\mathrm{CH}_{2}-\mathrm{CH}_{2}-\mathrm{O}$ units and contains the metal ion. The situation is different in the $\left[\mathrm{Sr}\left(\mathbf{L}^{2}\right)\left(\mathrm{ClO}_{4}\right)\right]^{+}$complex, where one of the pendant arms is folded towards the macrocyclic fragment containing $\mathrm{O}(3)$, and the second one towards that containing $\mathrm{O}(2)$. The distance between the nitrogen atoms of the crown moiety is considerably longer in the $\mathrm{Sr}(\mathrm{II})$ complex $(5.684 \AA)$ than in the $\mathrm{Ca}$ (II) one $(5.429 \AA)$, but shorter than that observed in the previously reported $\mathrm{Ba}(\mathrm{II})$ analog ${ }^{[31]}(5.825 \AA)$. These results show that the macrocyclic receptor possesses an important degree of flexibility, which allows fitting inside its cavity metal ions with different size.

Crystals of $\mathbf{4 b}$, $\mathbf{5 b}$ and $\mathbf{6}$ contain the cations $\left[\mathrm{Ca}\left(\mathbf{L}^{4}\right)\left(\mathrm{H}_{2} \mathrm{O}\right)\right]^{2+},\left[\mathrm{Sr}\left(\mathbf{L}^{4}\right)(\mathrm{MeOH})\right]^{2+}$ and $\left[\mathrm{Ba}\left(\mathbf{L}^{4}\right)\left(\mathrm{ClO}_{4}\right)\right]^{+}$, as well as perchlorate anions that are hydrogen bonded to the $\mathrm{NH}$ groups of benzimidazole groups, as previously observed for related complexes ${ }^{[20,23]}$. Views of the structures of the cations are shown in Fig. 3, Fig. 4, Fig. 5, while bond distances of the metal coordination environments are given in Table 4. The metal ions are directly bound to the eight donor atoms of the ligand in the three complexes. In the $\mathrm{Ca}$ (II) and $\mathrm{Sr}$ (II) compounds nine coordination is completed by an oxygen atom of a water $(\mathrm{Ca})$ or a methanol $(\mathrm{Sr})$ molecule. In the $\left[\mathrm{Ba}\left(\mathbf{L}^{4}\right)\left(\mathrm{ClO}_{4}\right)\right]^{+}$complex 10 coordination is completed by a perchlorate anion acting as a slightly asymmetrical bidentate ligand. A comparison of the bond distances given in Table 3, Table 4 shows that the distances between the metal ions and the donor atoms of the crown moiety are longer in the complexes of $\mathbf{L}^{4}$ than in the corresponding $\mathbf{L}^{2}$ analogs, which in turn are similar to those observed for related complexes with ligands derived from 4,13-diaza-18-crown- ${ }^{[48-50]}$. The opposite trend is observed when comparing the bond distances to donor atoms of the pendant arms, which are clearly shorter in $\mathbf{L}^{4}$ complexes than 
in $\mathbf{L}^{2}$ ones. This effect may be related to the different conformation adopted by the ligand in the complexes of $\mathbf{L}^{2}$ and $\mathbf{L}^{4}$. Indeed, while for the $\mathbf{L}^{2}$ complexes the ligand adopts an anti conformation (vide supra) in the $\mathbf{L}^{4}$ analogs the ligand adopts a syn conformation. In the case of the $\mathrm{Ba}$ (II) complex of $\mathbf{L}^{4}$ the perchlorate anion is coordinating to the metal ion from the side of the crown moiety where the pendant arms are situated, while in the $\mathrm{Ca}$ (II) and $\mathrm{Sr}(\mathrm{II})$ complexes the coordinated water (or methanol) molecule is located on the opposite side. The syn conformation of the ligand observed in the complexes of $\mathbf{L}^{4}$ appears to favor the interaction of the metal ion with the donor atoms of the pendant arms while weakening the bonds formed between the metal ions and the donor atoms of the crown moiety. The different conformations adopted by the ligand in the complexes of $\mathbf{L}^{2}$ and $\mathbf{L}^{4}$ can be attributed to the different sizes of the chelate rings formed upon coordination of the pendant arms. Indeed, coordination of the aniline pendants in $\mathbf{L}^{2}$ results in the formation of six-membered chelate rings, whereas coordination of the pendant arms of $\mathbf{L}^{4}$ forms fivemembered chelate rings. Moreover, the syn conformation of the ligand observed in the $\mathrm{Ca}(\mathrm{II}), \mathrm{Sr}(\mathrm{II})$ and $\mathrm{Ba}$ (II) complexes of $\mathbf{L}^{4}$ implies the occurrence of two helicities: one associated with the layout of the pendant arms (absolute configuration $\Delta$ or $\Lambda$, and the other to the six five-membered chelate rings formed by the binding of the crown moiety (each of them showing absolute configuration $\delta$ or $\lambda$ ) ${ }^{[51,52]}$. Inspection of crystals of $\mathbf{4 b}$ shows that the centrosymmetrically related $\Delta(\lambda \delta \delta)(\lambda \delta \delta)$ and $\Lambda(\delta \lambda \lambda)(\delta \lambda \lambda)$ enantiomers cocrystallize in equal amounts (racemate), where each term within parentheses represents the conformations of the three five-membered chelate rings formed by one of the $\mathrm{N}-\left(\mathrm{CH}_{2}\right)_{2}-\mathrm{O}-\left(\mathrm{CH}_{2}\right)_{2}-\mathrm{O}-\left(\mathrm{CH}_{2}\right)_{2}-\mathrm{N}$ moiety of the ligand backbone. A similar situation is observed for the $\mathrm{Ba}(\mathrm{II})$ analog, which crystallizes as a $\Delta(\delta \lambda \lambda)(\lambda \delta \lambda)-\Lambda(\lambda \delta \delta)(\delta \lambda \delta)$ enantiomeric pair. However, in the case of the $\operatorname{Sr}(\mathrm{II})$ complex only the $\Lambda(\delta \lambda \lambda)(\delta \lambda \lambda)$ enantiomer is observed in the crystal structure. The $\left[\mathrm{Ca}\left(\mathbf{L}^{4}\right)\left(\mathrm{H}_{2} \mathrm{O}\right)\right]^{2+}$ cations in $\mathbf{4 b}$ show an undistorted (crystallographically imposed) $C_{2}$ symmetry, while the $\left[\operatorname{Sr}\left(\mathbf{L}^{4}\right)(\mathrm{MeOH})\right]^{2+}$ cation presents a somewhat distorted $C_{2}$ symmetry.

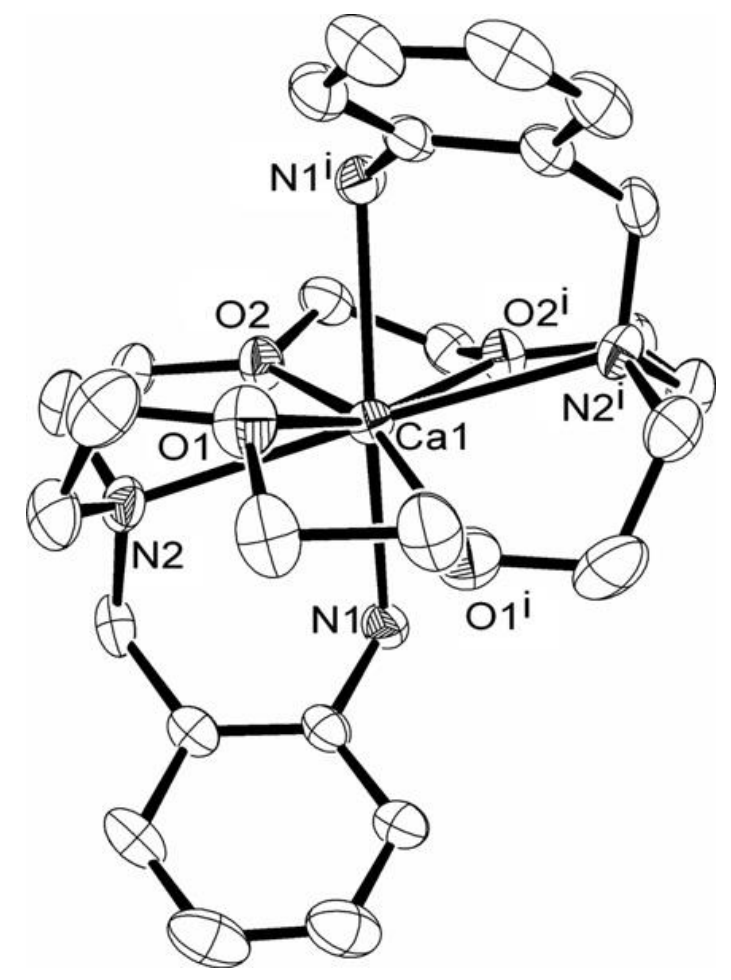

Fig. 1. View of the $\left[\mathrm{Ca}\left(\mathbf{L}^{2}\right)\right]^{2+}$ complex cation present in crystals of $\mathbf{1 b}$. The ORTEP plot is drawn at the $30 \%$ probability level. Hydrogen atoms are omitted for the sake of simplicity. 


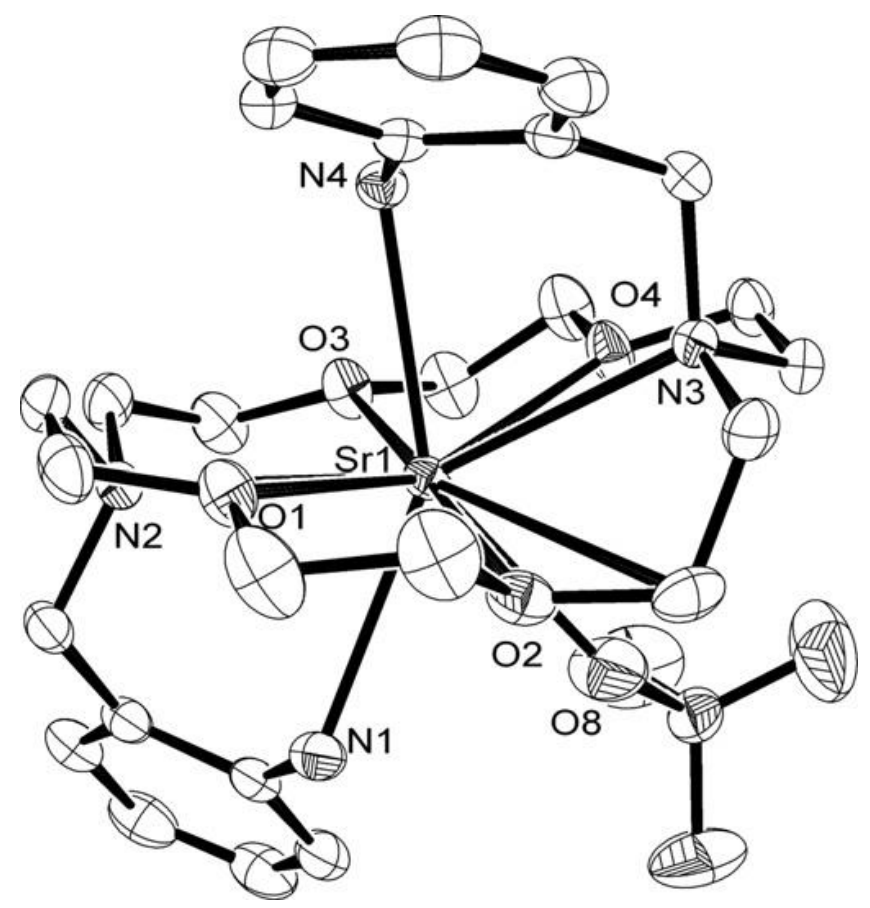

Fig. 2. View of the $\left[\mathrm{Sr}\left(\mathbf{L}^{2}\right)\left(\mathrm{ClO}_{4}\right)\right]^{+}$unit present in crystals of $\mathbf{2}$. The ORTEP plot is drawn at the $30 \%$ probability level. Hydrogen atoms are omitted for the sake of simplicity.

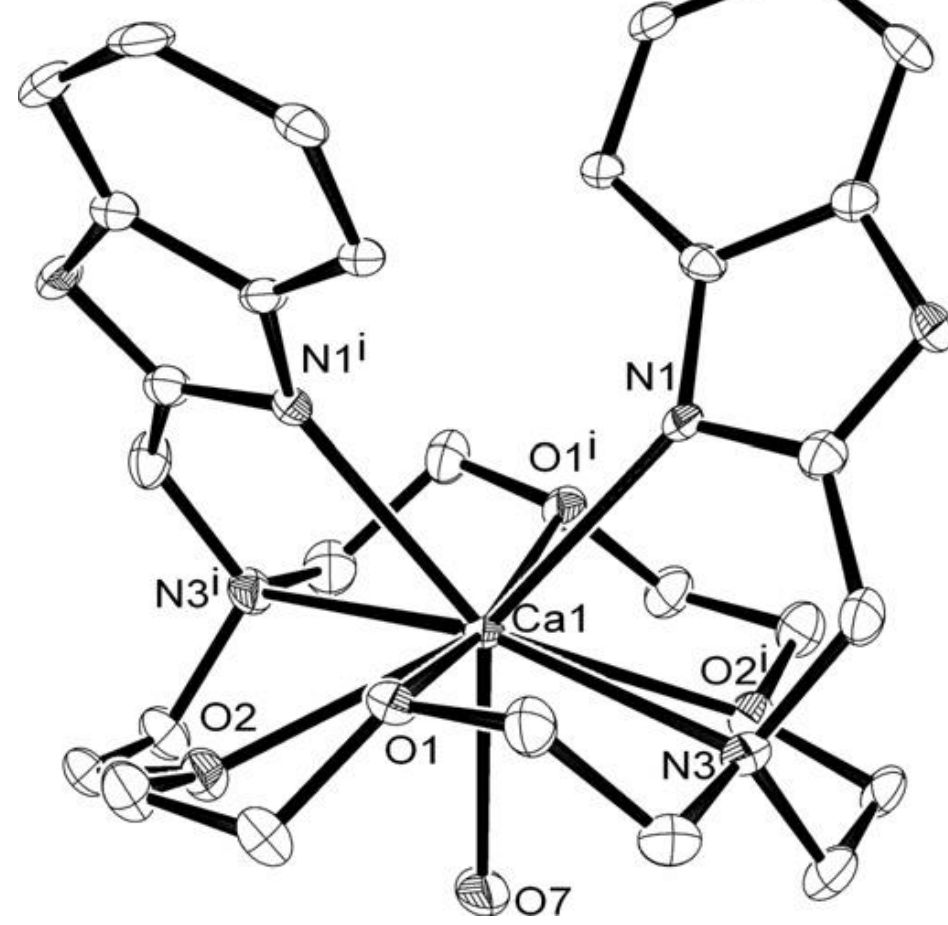

Fig. 3. View of the $\left[\mathrm{Ca}\left(\mathbf{L}^{\mathbf{4}}\right)\left(\mathrm{H}_{2} \mathrm{O}\right)\right]^{2+}$ unit present in crystals of $\mathbf{4 b}$. The ORTEP plot is drawn at the $30 \%$ probability level. Hydrogen atoms are omitted for the sake of simplicity. 


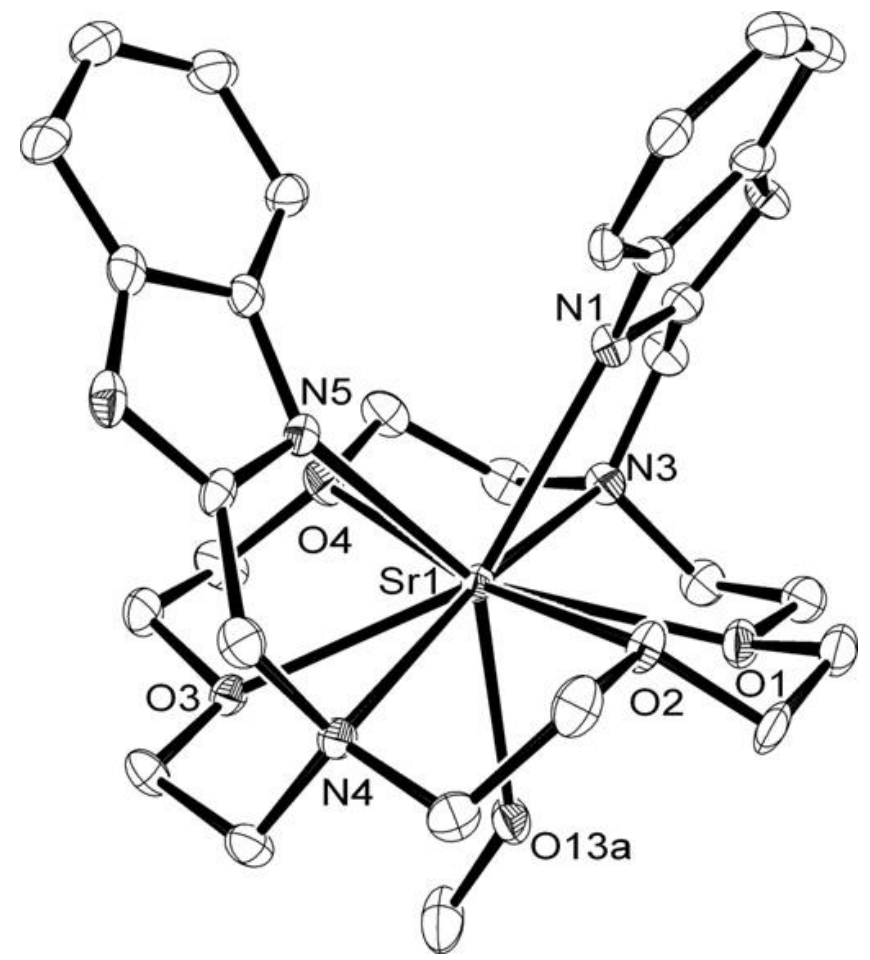

Fig. 4. View of the $\left[\mathrm{Sr}\left(\mathbf{L}^{4}\right)(\mathrm{MeOH})\right]^{2+}$ unit present in crystals of $\mathbf{5 b}$. The ORTEP plot is drawn at the $30 \%$ probability level. Hydrogen atoms are omitted for the sake of simplicity.

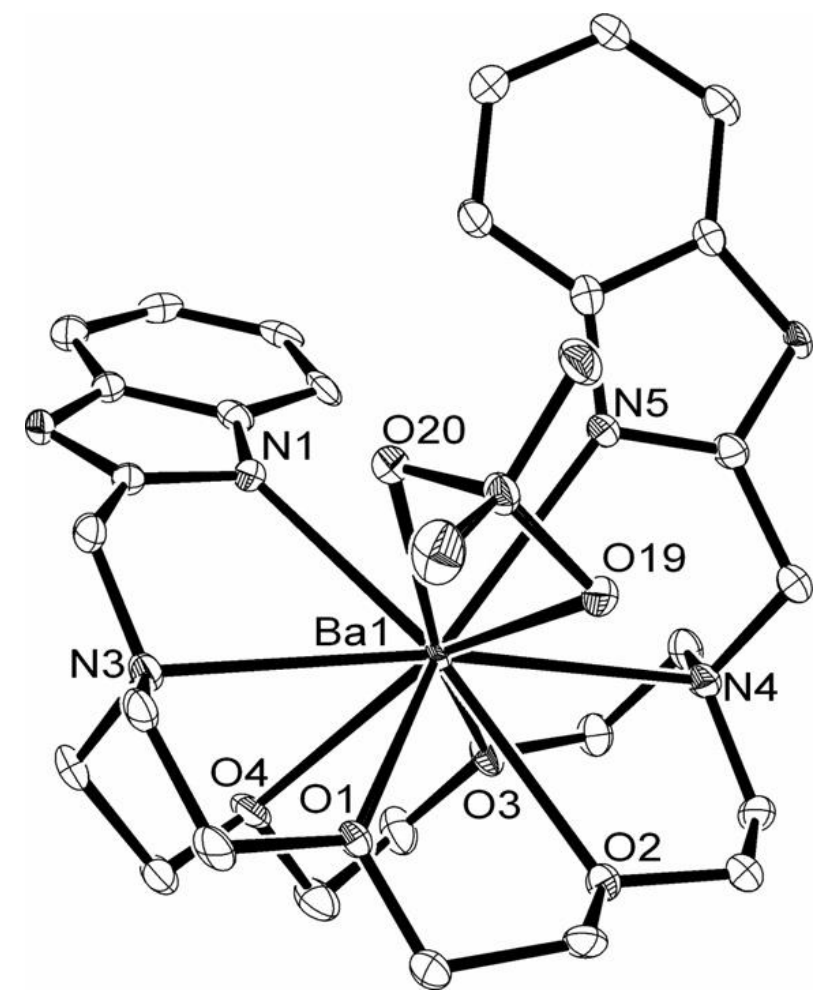

Fig. 5. View of the $\left[\mathrm{Ba}\left(\mathbf{L}^{4}\right)\left(\mathrm{ClO}_{4}\right)\right]^{+}$unit present in crystals of $\mathbf{6}$. The ORTEP plot is drawn at the $30 \%$ probability level. Hydrogen atoms are omitted for the sake of simplicity. 
Table 3. Selected bond lengths $(\AA)$ for $\mathbf{1 b}$ and $\mathbf{2}$.

\begin{tabular}{llll}
\hline & $\mathbf{1}$ & & $\mathbf{2}$ \\
\hline $\mathrm{Ca}(1)-\mathrm{O}(2)$ & $2.454(3)$ & $\mathrm{Sr}(1)-\mathrm{O}(3)$ & $2.593(2)$ \\
$\mathrm{Ca}(1)-\mathrm{O}(1)$ & $2.462(4)$ & $\mathrm{Sr}(1)-\mathrm{O}(2)$ & $2.610(2)$ \\
$\mathrm{Ca}(1)-\mathrm{N}(1)$ & $2.511(3)$ & $\mathrm{Sr}(1)-\mathrm{O}(4)$ & $2.614(2)$ \\
$\mathrm{Ca}(1)-\mathrm{N}(2)$ & $2.722(3)$ & $\mathrm{Sr}(1)-\mathrm{O}(8)$ & $2.650(3)$ \\
& & $\mathrm{Sr}(1)-\mathrm{O}(1)$ & $2.658(2)$ \\
& & $\mathrm{Sr}(1)-\mathrm{N}(4)$ & $2.723(2)$ \\
& $\mathrm{Sr}(1)-\mathrm{N}(1)$ & $2.754(3)$ \\
& $\mathrm{Sr}(1)-\mathrm{N}(2)$ & $2.924(2)$ \\
& $\mathrm{Sr}(1)-\mathrm{N}(3)$ & $2.931(2)$ \\
\hline
\end{tabular}

Table 4. Selected bond lengths $(\AA)$ for $\mathbf{3 b}, \mathbf{4 b}, \mathbf{5 b}$ and $\mathbf{6}$.

\begin{tabular}{llllllll}
\hline $\mathrm{Mg}(1)-\mathrm{O}(1 \mathrm{~W})$ & $1.983(3)$ & $\mathrm{Ca}(1)-\mathrm{O}(7)$ & $2.358(5)$ & $\mathrm{Sr}(1)-\mathrm{O}(13 \mathrm{~A})$ & $2.541(4)$ & $\mathrm{Ba}(1)-\mathrm{O}(1)$ & $2.813(3)$ \\
$\mathrm{Mg}(1)-\mathrm{O}(2 \mathrm{~W})$ & $2.000(3)$ & $\mathrm{Ca}(1)-\mathrm{N}(1)$ & $2.496(4)$ & $\mathrm{Sr}(1)-\mathrm{N}(5)$ & $2.614(4)$ & $\mathrm{Ba}(1)-\mathrm{O}(3)$ & $2.826(3)$ \\
$\mathrm{Mg}(1)-\mathrm{O}(4)$ & $2.083(3)$ & $\mathrm{Ca}(1)-\mathrm{O}(2)$ & $2.628(3)$ & $\mathrm{Sr}(1)-\mathrm{N}(1)$ & $2.635(4)$ & $\mathrm{Ba}(1)-\mathrm{N}(5)$ & $2.837(4)$ \\
$\mathrm{Mg}(1)-\mathrm{O}(3)$ & $2.113(3)$ & $\mathrm{Ca}(1)-\mathrm{O}(1)$ & $2.641(3)$ & $\mathrm{Sr}(1)-\mathrm{O}(1)$ & $2.677(4)$ & $\mathrm{Ba}(1)-\mathrm{O}(2)$ & $2.860(3)$ \\
$\mathrm{Mg}(1)-\mathrm{N}(1)$ & $2.177(3)$ & $\mathrm{Ca}(1)-\mathrm{N}(3)$ & $2.876(4)$ & $\mathrm{Sr}(1)-\mathrm{O}(4)$ & $2.688(4)$ & $\mathrm{Ba}(1)-\mathrm{O}(20)$ & $2.860(3)$ \\
$\mathrm{Mg}(1)-\mathrm{N}(3)$ & $2.327(3)$ & & & $\mathrm{Sr}(1)-\mathrm{O}(2)$ & $2.699(4)$ & $\mathrm{Ba}(1)-\mathrm{N}(1)$ & $2.874(4)$ \\
& & & & $\mathrm{Sr}(1)-\mathrm{O}(3)$ & $2.701(3)$ & $\mathrm{Ba}(1)-\mathrm{O}(4)$ & $2.906(4)$ \\
& & & & $\mathrm{Sr}(1)-\mathrm{N}(4)$ & $2.905(4)$ & $\mathrm{Ba}(1)-\mathrm{N}(4)$ & $2.987(4)$ \\
& & & & $\mathrm{Sr}(1)-\mathrm{N}(3)$ & $2.910(4)$ & $\mathrm{Ba}(1)-\mathrm{O}(19)$ & $2.998(4)$ \\
& & & & & & $\mathrm{Ba}(1)-\mathrm{N}(3)$ & $3.008(4)$ \\
\hline
\end{tabular}

Unlike its $\mathrm{Ca}(\mathrm{II}), \mathrm{Sr}(\mathrm{II})$ and $\mathrm{Ba}(\mathrm{II})$ analogs, in the $\mathrm{Mg}(\mathrm{II})$ complex with $\mathbf{L}^{\mathbf{4}}(\mathbf{3 b})$ an anti conformation is observed, with the two pendant arms pointing at opposite sides of the crown moiety (see Fig. 6). Moreover, the coordination sphere is also absolutely different and the magnesium ion is directly bound to only four of the eight donor atoms of the macrocycle: two oxygen atoms of the crown moiety $[\mathrm{O}(3)$ and $\mathrm{O}(4)]$, one of the pivotal nitrogen atoms $[\mathrm{N}(3)]$ and a nitrogen atom of one of the benzimidazole pendants (see Table 4 for bond distances). Coordination number six is completed by the presence of two inner-sphere water molecules $[\mathrm{O}(1 \mathrm{~W})$ and $\mathrm{O}(2 \mathrm{~W})]$. The water molecule containing $\mathrm{O}(1 \mathrm{~W})$ is involved in intramolecular hydrogen bonding interaction with one of the uncoordinated oxygen atoms of the crown moiety, $[\mathrm{O}(1 \mathrm{~W})-\mathrm{H}(11 \mathrm{~W}) 0.893(3) \AA$, $\mathrm{O}(2) \cdots \mathrm{H}(11 \mathrm{~W}) 1.734(3) \AA, \mathrm{O}(1 \mathrm{~W}) \cdots \mathrm{O}(2) 2.625(4), \mathrm{O}(1 \mathrm{~W})-\mathrm{H}(11 \mathrm{~W}) \cdots \mathrm{O}(2) 175.3(2)^{\circ}$ ], while the water molecule containing $\mathrm{O}(2 \mathrm{~W})$ is hydrogen-bonded to an oxygen atom of the crown moiety and a nitrogen atom of one of the benzimidazole groups $[\mathrm{O}(2 \mathrm{~W})-\mathrm{H}(22 \mathrm{~W}) 1.01(3) \AA, \mathrm{H}(22 \mathrm{~W}) \cdots \mathrm{O}(1) 2.08(2) \AA, \mathrm{O}(2 \mathrm{~W}) \cdots \mathrm{O}(1)$ $2.785(4) \AA, \quad \mathrm{O}(2 \mathrm{~W})-\mathrm{H}(22 \mathrm{~W}) \cdots \mathrm{O}(1) \quad 125(3)^{\circ} ; \mathrm{O}(2 \mathrm{~W})-\mathrm{H}(21 \mathrm{~W}) \quad 0.997(3) \AA, \mathrm{H}(21 \mathrm{~W}) \cdots \mathrm{N}(5) \quad 1.732(3) \AA$, $\left.\mathrm{O}(2 \mathrm{~W})-\mathrm{H}(21 \mathrm{~W}) \cdots \mathrm{N}(5) \quad 2.663(4) \AA, \quad \mathrm{O}(2 \mathrm{~W})-\mathrm{H}(21 \mathrm{~W}) \cdots \mathrm{N}(5) \quad 153.84(19)^{\circ}\right]$. The two uncoordinated perchlorate anions are involved in hydrogen bonding interaction with the $\mathrm{NH}$ groups of benzimidazole groups and the coordinated water molecule containing $\mathrm{O}(1 \mathrm{~W})$. In the $\left[\mathrm{Mg}\left(\mathrm{L}^{4}\right)\left(\mathrm{H}_{2} \mathrm{O}\right)_{2}\right]^{2+}$ complex, the metal ion shows a distorted octahedral coordination environment, where the trans angles $\mathrm{O}(1 \mathrm{~W})-\mathrm{Mg}(1)-\mathrm{O}(4)$ 
$\left[167.38(13)^{\circ}\right], \mathrm{O}(2 \mathrm{~W})-\mathrm{Mg}(1)-\mathrm{N}(1)\left[163.66(13)^{\circ}\right]$ and $\mathrm{O}(3)-\mathrm{Mg}(1)-\mathrm{N}(3)$ [155.81(13) $)^{\circ}$ show important deviations from the expected value of $180^{\circ}$. The cis angles in the corresponding equatorial planes range between $76.58(11)^{\circ}$ and $98.44(12)^{\circ}$.

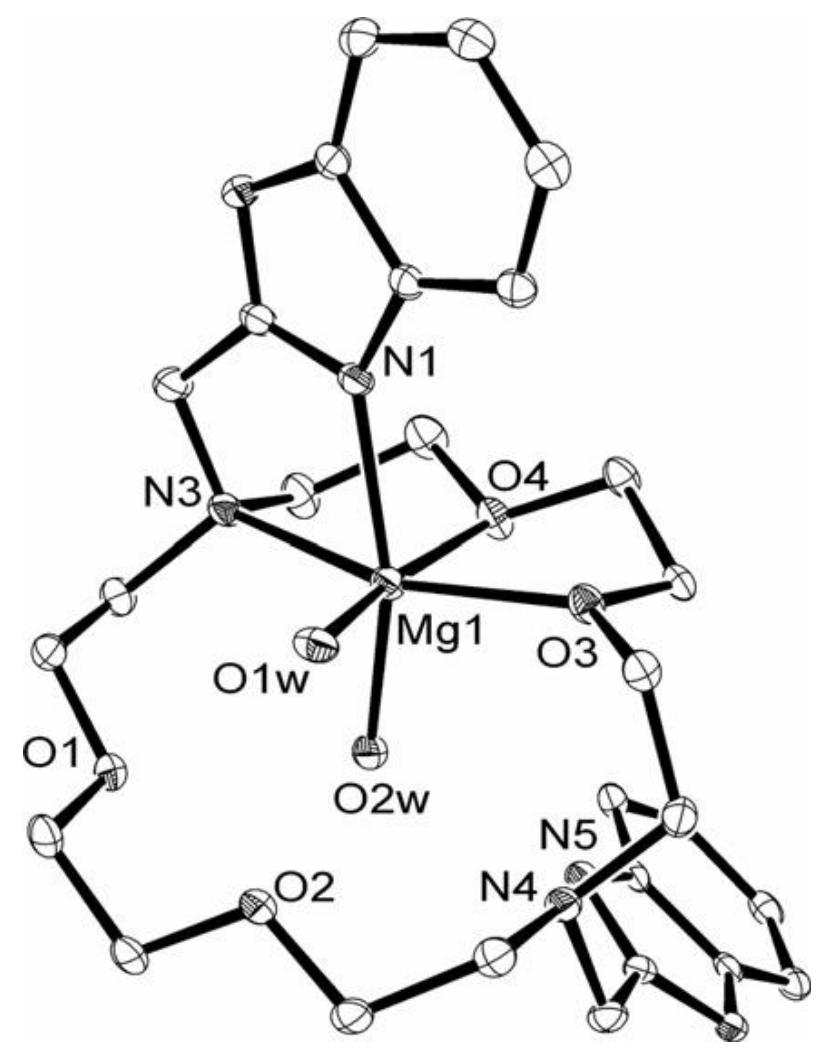

Fig. 6. View of the $\left[\mathrm{Mg}\left(\mathbf{L}^{4}\right)\left(\mathrm{H}_{2} \mathrm{O}\right)_{2}\right]^{2+}$ unit present in crystals of $\mathbf{3 b}$. The ORTEP plot is drawn at the $30 \%$ probability level. Hydrogen atoms are omitted for the sake of simplicity.

\subsection{Solution structure}

The ${ }^{1} \mathrm{H}$ and ${ }^{13} \mathrm{C}$ NMR spectra of the $\mathrm{Ca}(\mathrm{II}), \mathrm{Sr}(\mathrm{II})$ and $\mathrm{Ba}(\mathrm{II})$ complexes of $\mathbf{L}^{4}$ show well resolved signals (Fig. 7) that could be assigned with the aid of HSQC and HMBC 2D heteronuclear experiments, as well as standard 2D homonuclear COSY spectra (Table 5). The ${ }^{1} \mathrm{H}$ NMR spectra of the three complexes show two sets of signals with different intensities, which indicates the presence of two complex species in acetonitrile solution that are in slow exchange at $298 \mathrm{~K}$. For instance, two signals with different intensity are observed for the $\mathrm{NH}$ protons of benzimidazole groups. The ${ }^{13} \mathrm{C}$ NMR spectra confirm the presence of two complexes species in solution, as they show two sets of signals each consisting of 11 NMR peaks. The number of NMR signals observed for each species is consistent with an effective $C_{2 \mathrm{v}}$ or $C_{2 \mathrm{~h}}$ symmetry of the complexes in solution. Interestingly, the ${ }^{1} \mathrm{H}$ NMR signals due to aromatic protons are considerably more shielded for the species present in solution with the highest abundance. Similar shielding effects have been observed in lanthanide complexes with lariat ethers having a syn conformation, which have been explained by the observation that these protons are directed toward the aromatic ring current of the neighboring pendant arm ${ }^{[53]}$. On this basis, we assign the major species of $\left[\mathrm{M}\left(\mathbf{L}^{4}\right)\right]^{2+}$ complexes in solution $(\mathrm{M}=\mathrm{Ca}, \mathrm{Sr}$ or $\mathrm{Ba})$ to a complex species with a syn arrangement of the pendant arms, while the minor species is assigned to an anti isomer. This assignment is supported by our DFT calculations described below, and by the fact that an equilibrium in solution between the syn and anti conformations has been previously established for the 
$\left[\mathrm{Ba}\left(\mathbf{L}^{2}\right)\right]^{2+}$ complex ${ }^{[31]}$. The equilibrium between the syn and anti isomers of $\left[\mathrm{M}\left(\mathbf{L}^{4}\right)\right]^{2+}$ complexes in solution $(\mathrm{M}=\mathrm{Ca}, \mathrm{Sr}$ or $\mathrm{Ba})$ may be expressed as:

$$
\left[\mathrm{M}\left(\mathbf{L}^{\mathbf{4}}\right)\right]_{\text {anti }}^{2+} \leftrightarrows\left[\mathrm{M}\left(\mathbf{L}^{\mathbf{4}}\right)\right]_{\text {syn }}^{2+}
$$

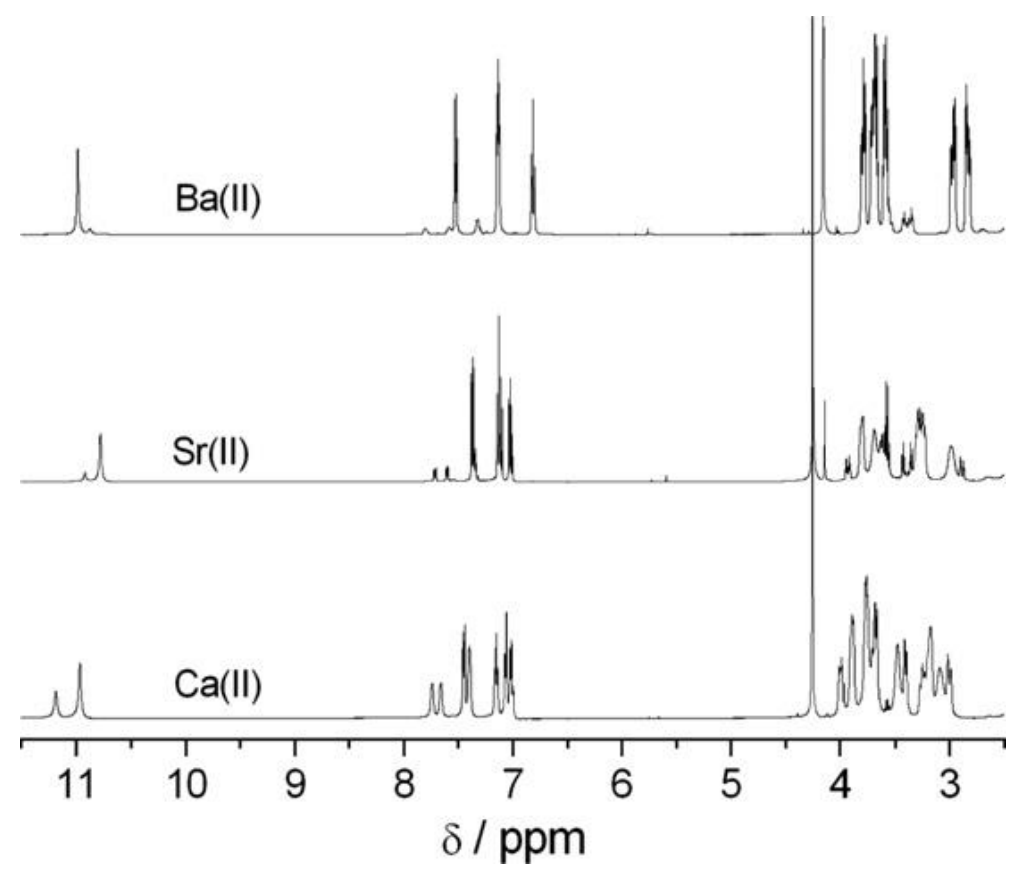

Fig. 7. ${ }^{1} \mathrm{H}$ NMR spectra $(500 \mathrm{MHz})$ of $\left[\mathrm{M}\left(\mathbf{L}^{4}\right)\right]^{2+}(\mathrm{M}=\mathrm{Ca}, \mathrm{Sr}$ or $\mathrm{Ba})$ complexes recorded in $\mathrm{CD}_{3} \mathrm{CN}$ solution at $298 \mathrm{~K}$.

The equilibrium constant defined by this equation, $K_{\mathrm{eq}}$, was determined at several temperatures between 238 and $298 \mathrm{~K}$ from the relative integrations of the ${ }^{1} \mathrm{H}$ NMR signals due to $\mathrm{NH}$ protons of the benzimidazole groups. The values of $K_{\text {eq }}$ obtained at $298 \mathrm{~K}$ are listed in Table 6 . For the $\mathrm{Sr}$ (II) and $\mathrm{Ba}$ (II) complexes the ratio between the intensity of the peaks corresponding to the syn and anti species was found to be nearly constant in the range of temperatures investigated. This indicates that $\Delta S^{\circ} \sim 0$ for the dynamic equilibrium described by Eq. (1), indicating that the interconversion process between the two species present in solution follows an intramolecular rearrangement. However, in the case of the $\mathrm{Ca}$ (II) complex the relative intensity of the two signals due to $\mathrm{NH}$ protons changes substantially with temperature (Fig. 8). The temperature dependence of the relative intensities of the two bands was used to calculate $K_{\text {eq }}$ at different temperatures. A plot of $\ln K_{\text {eq }}$ versus $1 / T\left(R^{2}>0.997\right)$ was used to determine the reaction enthalpy, $\Delta H^{\circ}=-9.8 \pm 0.3 \mathrm{~kJ} \mathrm{~mol}^{-1}$, and the reaction entropy, $\Delta S^{\circ}=-28.0 \pm 1.1 \mathrm{~J} \mathrm{~mol}^{-1} \mathrm{~K}^{-1}$. The negative value of the reaction entropy, suggests that solvent molecules could be involved in coordination to the syn isomer of $\left[\mathrm{Ca}\left(\mathbf{L}^{4}\right)\right]^{2+}$ according to the following expression:

$$
\left[\mathrm{Ca}\left(\mathbf{L}^{\mathbf{4}}\right)\right]_{\text {anti }}^{2+}+\mathrm{H}_{2} \mathrm{O} \leftrightarrows\left[\mathrm{Ca}\left(\mathbf{L}^{4}\right)\left(\mathrm{H}_{2} \mathrm{O}\right)\right]_{\text {syn }}^{2+}
$$


Table 5. ${ }^{1} \mathrm{H}$ and ${ }^{13} \mathrm{C}$ NMR spectral data [ppm with respect to TMS] in $\mathrm{CD}_{3} \mathrm{CN}(298 \mathrm{~K})$. See Scheme 1 for labeling.

\begin{tabular}{|c|c|c|c|c|c|}
\hline & syn & anti & & syn & anti \\
\hline \multicolumn{6}{|c|}{$\left[\mathrm{Ca}\left(\boldsymbol{L}^{4}\right)\right]^{2+}$} \\
\hline $\mathrm{H} 2$ & 7.41 & 7.63 & $\mathrm{C} 1$ & 134.6 & 134.8 \\
\hline H3 & 7.12 & 7.37 & $\mathrm{C} 2$ & 112.7 & 113.1 \\
\hline $\mathrm{H} 4$ & 6.98 & 7.37 & $\mathrm{C} 3$ & 124.4 & 124.8 \\
\hline H5 & 7.03 & 7.71 & $\mathrm{C} 4$ & 123.7 & 124.2 \\
\hline H8 & 4.22 & 4.22 & C5 & 118.4 & 118.9 \\
\hline H9ax & 3.06 & 2.97 & C6 & 141.8 & 141.9 \\
\hline H9eq & 3.14 & 3.22 & C7 & 155.3 & 155.7 \\
\hline H10ax & 3.68 & 3.64 & $\mathrm{C} 8$ & 54.3 & 52.1 \\
\hline H10eq & 3.87 & 3.96 & C9 & 56.7 & 56.3 \\
\hline H11ax & 3.45 & 3.37 & $\mathrm{C} 10$ & 69.4 & 68.8 \\
\hline H11eq & 3.75 & 3.72 & $\mathrm{C} 11$ & 70.5 & 70.3 \\
\hline $\mathrm{NH}$ & 10.93 & 11.15 & & & \\
\hline \multicolumn{6}{|c|}{$\left[\operatorname{Sr}\left(\boldsymbol{L}^{4}\right)\right]^{2+}$} \\
\hline $\mathrm{H} 2$ & 7.33 & 7.57 & $\mathrm{C} 1$ & 134.4 & 134.9 \\
\hline H3 & 7.08 & 7.32 & $\mathrm{C} 2$ & 112.4 & 112.7 \\
\hline $\mathrm{H} 4$ & 6.99 & 7.32 & $\mathrm{C} 3$ & 124.1 & 124.3 \\
\hline H5 & 7.10 & 7.68 & $\mathrm{C} 4$ & 123.4 & 123.7 \\
\hline H8 & 4.22 & 4.11 & C5 & 118.5 & 119.3 \\
\hline H9ax & 2.96 & 2.86 & C6 & 142.3 & 142.9 \\
\hline H9eq & 3.21 & 3.26 & C7 & 155.1 & 155.1 \\
\hline H10ax & 3.62 & 3.59 & $\mathrm{C} 8$ & 54.8 & 51.3 \\
\hline H10eq & 3.78 & 3.90 & C9 & 58.1 & 56.8 \\
\hline H11ax & 3.26 & 3.32 & $\mathrm{C} 10$ & 69.4 & 69.4 \\
\hline H11eq & 3.66 & 3.40 & $\mathrm{C} 11$ & 70.9 & 70.6 \\
\hline $\mathrm{NH}$ & 10.74 & 10.89 & & & \\
\hline \multicolumn{6}{|c|}{$\left[B a\left(\boldsymbol{L}^{4}\right)\right]^{2+}$} \\
\hline $\mathrm{H} 2$ & 7.49 & 7.55 & $\mathrm{C} 1$ & 134.4 & 134.8 \\
\hline $\mathrm{H} 3$ & 7.10 & 7.29 & $\mathrm{C} 2$ & 112.3 & 112.6 \\
\hline $\mathrm{H} 4$ & 6.78 & 7.29 & $\mathrm{C} 3$ & 123.9 & 124.1 \\
\hline H5 & 7.10 & 7.77 & $\mathrm{C} 4$ & 122.8 & 123.4 \\
\hline H8 & 4.12 & 4.12 & C5 & 120.2 & 119.7 \\
\hline H9ax & 2.80 & $a$ & C6 & 143.1 & 143.2 \\
\hline H9eq & 2.94 & $a$ & C7 & 154.7 & 155.3 \\
\hline H10ax & 3.68 & $a$ & $\mathrm{C} 8$ & 54.2 & 52.0 \\
\hline H10eq & 3.76 & $a$ & C9 & 55.4 & 58.0 \\
\hline H11ax & 3.56 & 3.32 & $\mathrm{C} 10$ & 69.4 & 70.0 \\
\hline H11eq & 3.65 & 3.39 & $\mathrm{C} 11$ & 71.0 & 71.1 \\
\hline $\mathrm{NH}$ & 10.95 & 10.84 & & & \\
\hline
\end{tabular}

${ }^{a}$ Not assigned. 
Table 6. $K_{\text {eq }}$ values obtained at $298 \mathrm{~K}$ for the anti $\leftrightarrows$ syn equilibrium observed in $\left[\mathrm{M}\left(\mathbf{L}^{2}\right)\right]^{2+}$ and $\left[\mathrm{M}\left(\mathbf{L}^{\mathbf{4}}\right)\right]^{2+}$ complexes $(\mathrm{M}=\mathrm{Ca}, \mathrm{Sr}$ or $\mathrm{Ba})$.

\begin{tabular}{llll}
\hline & Ca & Sr & Ba \\
\hline$\left[\mathrm{M}\left(\mathbf{L}^{2}\right)\right]^{2+}$ & $0.09 \pm 0.01$ & $\sim 1$ & $2.9^{a}$ \\
{$\left[\mathrm{M}\left(\mathbf{L}^{4}\right)\right]^{2+}$} & $1.73 \pm 0.05$ & $4.6 \pm 0.1$ & $5.1 \pm 0.2$ \\
\hline
\end{tabular}

${ }^{a}$ Ref. 31 .
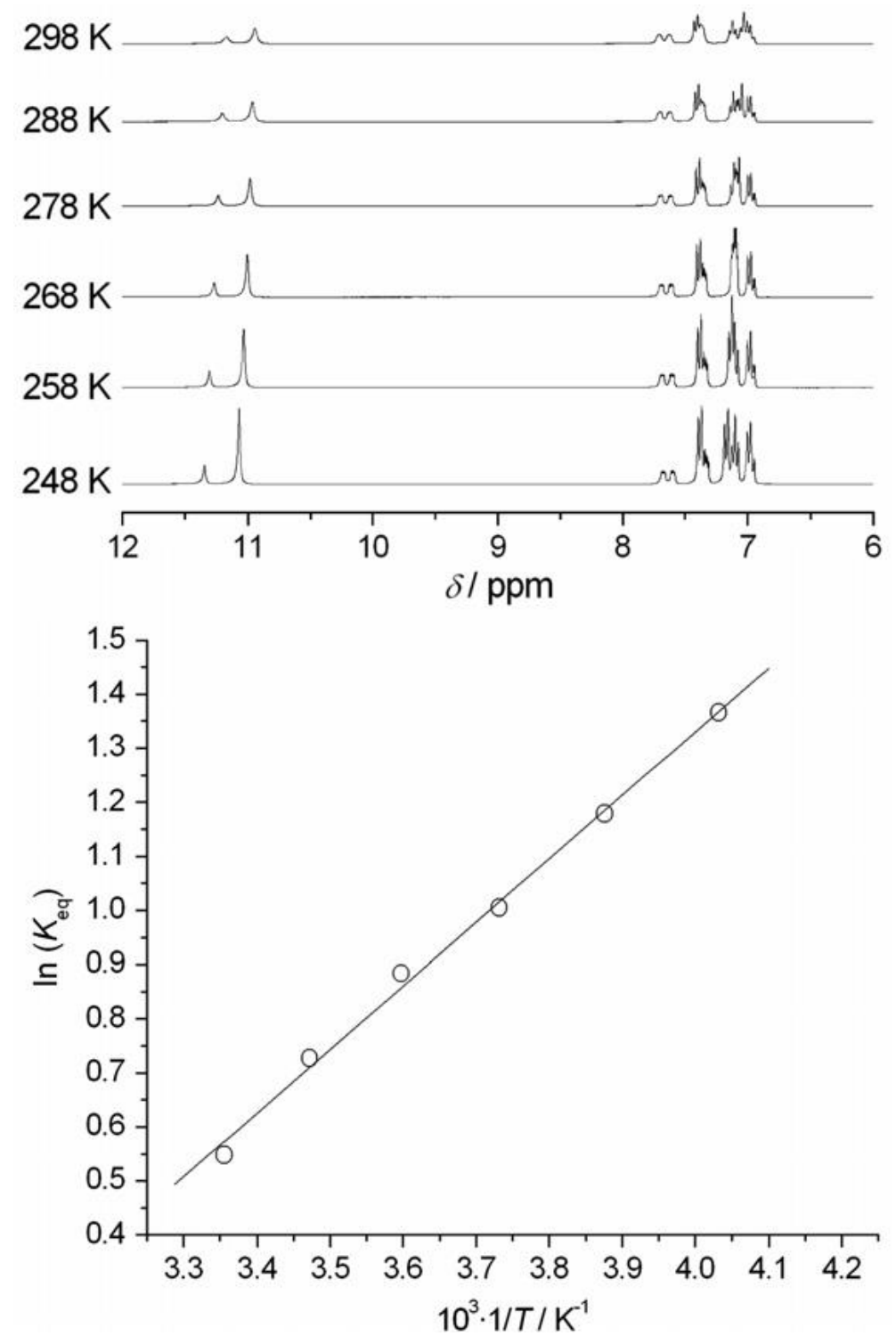

Fig. 8. Top: partial ${ }^{1} \mathrm{H}$ NMR spectra of $\left[\mathrm{Ca}\left(\mathbf{L}^{4}\right)\right]^{2+}$ recorded in $\mathrm{CD}_{3} \mathrm{CN}$ solution at different temperatures. Bottom: Plot of $\ln \left(K_{\text {eq }}\right)$ versus $1 / T$ for $\left[\mathrm{Ca}\left(\mathbf{L}^{4}\right)\right]^{2+}$. 
The presence of an inner-sphere water molecule in the syn isomer of $\left[\mathrm{Ca}\left(\mathbf{L}^{4}\right)\right]^{2+}$ is in agreement with the Xray crystal structure of this compound described above.

The ${ }^{1} \mathrm{H}$ NMR spectrum of the analogous $\mathrm{Mg}(\mathrm{II})$ complex of $\mathbf{L}^{4}$ recorded at room temperature in $\mathrm{CD}_{3} \mathrm{CN}$ solution shows broad signals in the range $2.5-4.5 \mathrm{ppm}$ as a consequence of exchange phenomena. Decreasing the temperature to $238 \mathrm{~K}$ did not result in better resolved spectrum, and therefore a specific assignment of the NMR signals was not possible. A similar situation is observed for the $\mathrm{Ca}$ (II) and $\mathrm{Sr}$ (II) complexes of $\mathbf{L}^{2}$. In spite of the presence of broad and poorly defined ${ }^{1} \mathrm{H}$ NMR signals that prevented a detailed assignment of the spectra of $\left[\mathrm{M}\left(\mathbf{L}^{2}\right)\right]^{2+}$ complexes, some light over their structures in solution was thrown by their NMR spectra. So, at $298 \mathrm{~K}$ the ${ }^{1} \mathrm{H}$ NMR spectrum of the $\mathrm{Sr}$ (II) complex shows one signal due to $\mathrm{NH}_{2}$ protons that, upon decreasing the temperature, gradually broadens and finally splits into two different resonances of very similar intensity. These results suggest that the syn and anti isomers are present in very similar populations in acetonitrile solution. In the case of the $\left[\mathrm{Ca}\left(\mathbf{L}^{2}\right)\right]^{2+}$ complex two different sets of ${ }^{1} \mathrm{H}$ NMR signals are observed for the aromatic protons at $298 \mathrm{~K}$; the relative intensity of these signals allowed to obtain the $K_{\text {eq }}$ value given in Table 6.

A close inspection of the $K_{\text {eq }}$ values shown in Table 6 allows us to extract several conclusions: (i) The relative abundance of the syn conformation increases as the ionic radius of the metal ion increases and (ii) for a given metal ion the proportion of syn isomer is always higher for $\mathbf{L}^{4}$ complexes than for $\mathbf{L}^{2}$ ones.

Aiming to get more information about the structure in solution of the $\left[\mathrm{M}\left(\mathbf{L}^{2}\right)\right]^{2+}(\mathbf{M}=\mathrm{Ca}$ or $\mathrm{Sr})$ and $\left[\mathrm{M}\left(\mathbf{L}^{4}\right)\right]^{2+}(\mathbf{M}=\mathrm{Ca}, \mathrm{Sr}$ or Ba) complexes we have performed DFT calculations based on the B3LYP model. In these calculations we have used the LANL2DZ effective core potential (ECP) for the metals, while the remaining atoms were described by using the 6-31G(d) basis set. A detailed investigation of the conformational space by performing geometry optimizations from different input geometries with different orientations of the six-membered chelate rings formed upon coordination of the crown moiety $(\delta$ or $\lambda)$, and different orientation of the pendant arms (absolute configuration $\Delta$ or $\Lambda$ ) have been carried out. The minimum energy conformations obtained for the $\left[\mathrm{M}\left(\mathbf{L}^{2}\right)\right]^{2+}$ and $\left[\mathrm{M}\left(\mathbf{L}^{4}\right)\right]^{2+}$ complexes from DFT calculations are shown in Fig. 9. In the case of the $\left[M\left(\mathbf{L}^{4}\right)\right]^{2+}$ complexes our calculations predict a minimum energy conformation in which the pendant arms of the ligand adopt a syn conformation, in nice agreement with the $\mathrm{X}$-ray crystal structures above described. However, the situation is different for $\mathbf{L}^{2}$ derivatives. Indeed, while for the $\left[\operatorname{Sr}\left(\mathbf{L}^{2}\right)\right]^{2+}$ complex the minimum energy conformation corresponds to a syn isomer, for the $\mathrm{Ca}(\mathrm{II})$ analog the anticonformation appears to be more stable than the syn one. The minimum energy conformations obtained for both the $\left[\mathrm{M}\left(\mathbf{L}^{2}\right)\right]^{2+}$ and $\left[\mathrm{M}\left(\mathbf{L}^{4}\right)\right]^{2+}$ complexes show nearly undistorted $C_{2}$ symmetries.

The relative energies of the syn and anti conformations with the lowest energy obtained for the $\left[\mathrm{M}\left(\mathbf{L}^{2}\right)\right]^{2+}$ and $\left[\mathrm{M}\left(\mathbf{L}^{4}\right)\right]^{2+}$ complexes are shown in Fig. 10. Our calculations indeed predict fairly low relative energies of the syn and anti conformations, which supports that syn and anti isomers are both present in a dynamic equilibrium in solution. For the $\left[\mathrm{M}\left(\mathbf{L}^{2}\right)\right]^{2+}$ complexes $(\mathrm{M}=\mathrm{Ca}$ or $\mathrm{Sr})$ our calculations predict an stabilization of the anti conformation upon decreasing the ionic radius of the metal ion, in nice agreement with the experimental trend observed in solution. Furthermore, a reasonably good agreement between the experimental and calculated relative free energies is observed (within $4.6 \mathrm{~kJ} \mathrm{~mol}^{-1}$ ). The quantitative agreement is even better for the $\left[\mathrm{M}\left(\mathbf{L}^{4}\right)\right]^{2+}$ complexes, the largest deviation between the experimental and calculated values being observed for the $\mathrm{Ba}$ (II) analog $\left(3.6 \mathrm{~kJ} \mathrm{~mol}^{-1}\right)$. In contrast to the experimental evidence, for the $\mathrm{Sr}$ (II) complex of $\mathbf{L}^{4}$ the syn conformation is slightly less stable than for the $\mathrm{Ca}(\mathrm{II})$ analog. This anomalous result could be related to the fact that our calculations were performed in the gas-phase and did not take into account the possible participation of solvent molecules or counterions in the coordination to the metal ions. 


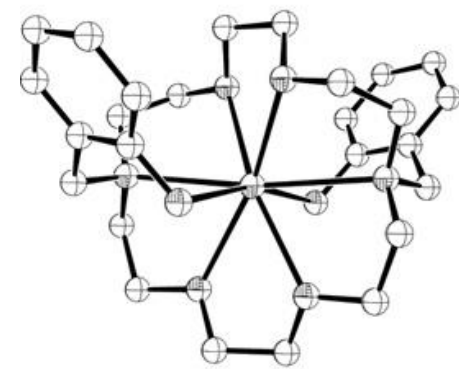

$\left[\mathrm{Ca}\left(\mathrm{L}^{2}\right)\right]^{2+}$

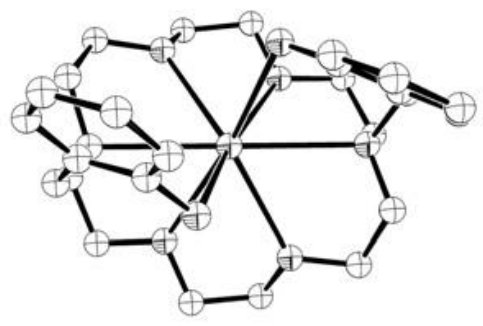

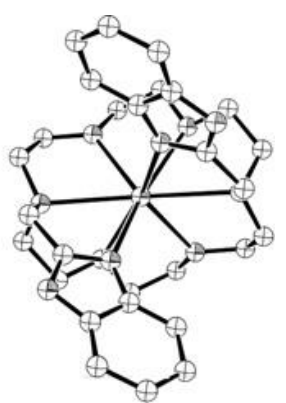

$\left[\mathrm{Ca}\left(\mathrm{L}^{4}\right)\right]^{2+}$

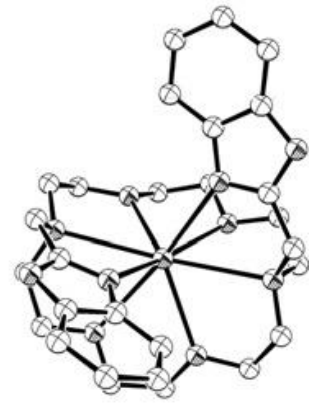

$\left[\operatorname{Sr}\left(L^{2}\right)\right]^{2+}$

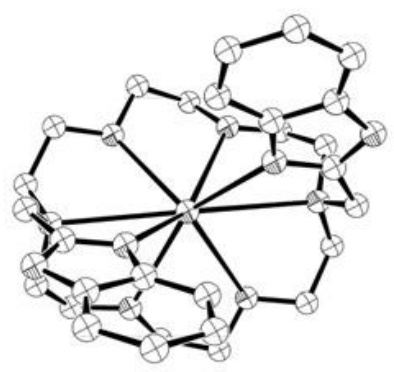

$\left[\mathrm{Ba}\left(\mathrm{L}^{4}\right)\right]^{2+}$

Fig. 9. DFT optimized geometries of the $\left[M\left(\mathbf{L}^{2}\right)\right]^{2+}(M=C a$ or $\mathrm{Sr})$ and $\left[M\left(\mathbf{L}^{4}\right)\right]^{2+}(M=C a$, Sr or Ba) complexes.

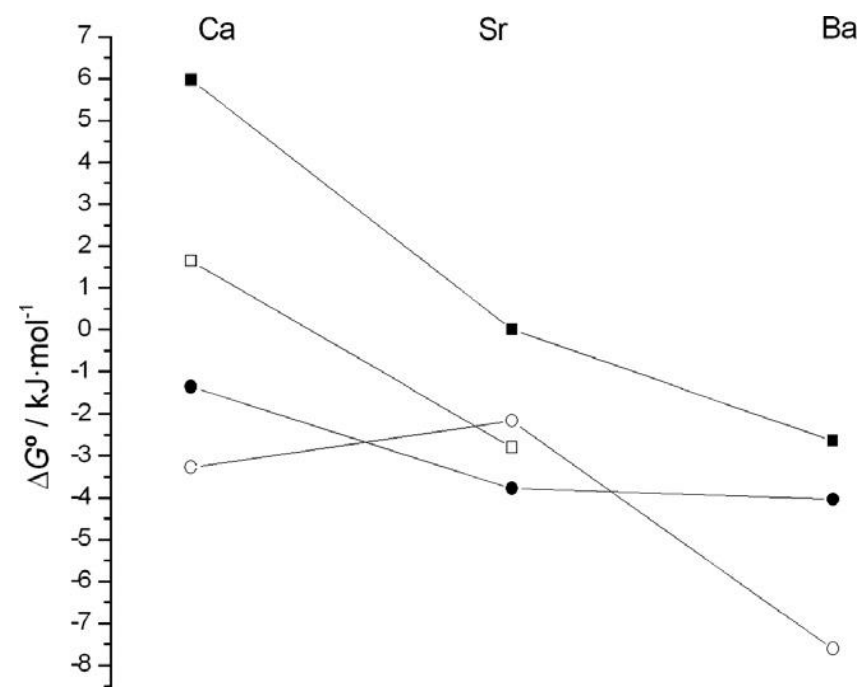

Fig. 10. Experimental (closed symbols) and calculated (open symbols) free energies obtained at $298 \mathrm{~K}$ for the anti $\leftrightarrows$ syn equilibrium in $\left[\mathrm{M}\left(\mathbf{L}^{2}\right)\right]^{2+}$ (squares) and $\left[\mathrm{M}\left(\mathbf{L}^{4}\right)\right]^{2+}$ (circles) complexes $(\mathrm{M}=\mathrm{Ca}, \mathrm{Sr}$ or $\mathrm{Ba})$. 


\section{Conclusions}

In this work, we have demonstrated that the nature of the pendant arms present in pendant armed macrocycles derived from 4,13-diaza-18-crown-6 may cause a determinant effect in the final conformation adopted by the receptor in a complex. So, we have proved that in the solid state complexes of $\mathrm{Ca}(\mathrm{II}), \mathrm{Sr}(\mathrm{II})$ and $\mathrm{Ba}$ (II) with the aniline pendant-armed diazacrown 4,13-diaza-18-crown-6 ( $\left.\mathbf{L}^{2}\right)$ display an anti conformation, whereas the analogous complexes with the receptor derived from the same diazacrown but containing benzimidazole pendants $\left(\mathbf{L}^{4}\right)$ show a syn conformation. In acetonitrile solution, however, both syn and anti isomers are involved in a dynamic equilibrium for all cases, independently of the nature of the pendant arm. DFT calculations performed with the aid of the hybrid B3LYP functional predict a small energy difference between the syn and anti forms, which is consistent with the two forms being populated in solution. Our results also show that the relative abundance of the syn conformation in solution increases as the ionic radius of the metal ion increases and, furthermore, for a given metal ion the proportion of syn isomer is always higher for $\mathbf{L}^{4}$ complexes than for $\mathbf{L}^{2}$ ones.

\section{Acknowledgements}

The authors thank Xunta de Galicia (PGIDIT06TAM10301PR and INCITE09E1R103013ES) for generous financial support. The authors are also indebted to Centro de Supercomputación de Galicia (CESGA) for providing the computer facilities. I.C.-B, A.R.-R. and M.R.-F. thank the Spanish Ministerio de Educación y Ciencia (FPU program) for predoctoral fellowships.

\section{Supplementary data}

CCDC 825765, 825766, 825767, 825768, 825769, 825770, 825771, 825772, 825773, 825774 and 825775 contain the supplementary crystallographic data for compounds $13, \mathbf{1 b}, \mathbf{2 b}, \mathbf{3 b}, \mathbf{4 b}, \mathbf{5 b}, \mathbf{6 b}, \mathbf{7 b}, \mathbf{8}, \mathbf{9 b}$ and $\mathbf{L}^{\mathbf{3}}$, respectively. These data can be obtained free of charge via http://www.ccdc.cam.ac.uk/conts/retrieving.html, or from the Cambridge Crystallographic Data Centre, 12 Union Road, Cambridge CB2 1EZ, UK; fax: (+44) 1223-336-033; or e-mail: deposit@ccdc.cam.ac.uk.

\section{References}

[1] H.-J. Schneider, A.K. Yatsimirsky, Chem. Soc. Rev. 37 (2008) 263.

[2] G.W. Gokel, W.M. Leevy, M.E. Weber, Chem. Rev. 248 (2004) 2723.

[3] C.J. Pederson, J.-M. Lehn, D.J. Cram, Resonante 6 (2001) 71.

[4] J.W. Steed, Coord. Chem. Rev. 215 (2001) 171.

[5] G.W. Gokel, S.H. Korzeniowski, Macrocyclic Polyether Synthesis, Springer, Berlin, 1982.

[6] G.W. Gokel, Comprehensive supramolecular chemistry, in: G.W. Gokel (Ed.), Lariat Ethers, vol. 1, Pergammon, New York, 1996, pp 97-152.

[7] V.K. Gupta, M.K. Pal, A.K. Singh, Anal. Chim. Acta 631 (2009) 161.

[8] P. Buhlmann, E. Pretsch, E. Bakker, Chem. Rev. 98 (1998) 1593. 
[9] M.H. Hyun, J. Sep. Sci. 26 (2003) 242.

[10] A.V. Tsukanov, A.D. Dubonosov, V.A. Bren, V.I. Minkin, Chem. Hetercycl. Comp. 44 (2008) 899.

[11] I. Moczar, P. Huszthy, A. Mezei, M. Kadar, J. Nyitrai, K. Toth, Tetrahedron 66 (2010) 350.

[12] V.I. Minkin, A.D. Dubonosov, V.A. Bren, A.V. Tsukanov, ARKIVOK (2008) 90.

[13] N. Basilio, L. Garcia-Rio, J.C. Mejuto, M. Perez-Lorenzo, J. Org. Chem. 71 (2006) 4280.

[14] S. Shirakawa, K. Yamamoto, M. Kitamura, T. Ooi, K. Maruoka, Angew. Chem., Int. Ed. 44 (2005) 625.

[15] K. Marijeta, L. Tusek-Bozic, L. Frkanec, ChemMedChem 3 (2008) 1478.

[16] A. Casnati, A. Pochini, R. Húngaro, C. Bocchi, F. Ugozzoli, R.J.M. Egberink, H. Struijk, R. Lugtenberg, F. de Jong, D.N. Reinhoudt, Chem. Eur. J. 2 (1996) 436.

[17] L. Vaiana, C. Platas-Iglesias, D. Esteban-Gomez, F. Avecilla, A. de Blas, T. Rodríguez-Blas, Eur. J. Inorg. Chem. (2007) 1874.

[18] D. Esteban, D. Bañobre, A. de Blas, T. Rodríguez-Blas, R. Bastida, A. Macías, A. Rodríguez, D.E. Fenton, H. Adams, J. Mahía, Eur. J. Inorg. Chem. (2000) 1445.

[19] D. Esteban, F. Avecilla, C. Platas-Iglesias, J. Mahía, A. de Blas, T. Rodríguez-Blas, Inorg. Chem. 41 (2002) 4337.

[20] M. Regueiro-Figueroa, D. Esteban-Gómez, C. Platas-Iglesias, A. de Blas, T. Rodríguez-Blas, Eur. J. Inorg. Chem. (2007) 2198.

[21] D. Esteban, F. Avecilla, C. Platas-Iglesias, A. de Blas, T. Rodríguez-Blas, Polyhedron 22 (2003) 2709.

[22] L. Vaiana, C. Platas-Iglesias, D. Esteban-Gómez, F. Avecilla, J.M. Clemente-Juan, J.A. Real, A. de Blas, T. Rodríguez-Blas, Dalton Trans. (2005) 2031.

[23] L. Vaiana, D. Esteban-Gomez, M. Mato-Iglesias, C. Platas-Iglesias, A. de Blas, T. Rodríguez-Blas, Eur. J. Inorg. Chem. (2009) 400.

[24] C. Platas-Iglesias, L. Vaiana, D. Esteban-Gómez, F. Avecilla, J.A. Real, A. de Blas, T. Rodríguez-Blas, Inorg. Chem. 44 (2005) 9704.

[25] C. Rodríguez-Infante, D. Esteban, F. Avecilla, A. de Blas, T. Rodríguez-Blas, J. Mahia, A.L. Macedo, C.F.G.C. Geraldes, Inorg. Chim. Acta 317 (2001) 190.

[26] L. Vaiana, M. Regueiro-Figueroa, M. Mato-Iglesias, C. Platas-Iglesias, D. Esteban-Gomez, A. de Blas, T. Rodríguez-Blas, Inorg. Chem. 46 (2007) 8271.

[27] D. Esteban-Gomez, C. Platas-Iglesias, F. Avecilla, A. de Blas, T. Rodríguez-Blas, Eur. J. Inorg. Chem. (2007) 1635.

[28] D. Esteban-Gomez, R. Ferreiros, S. Fernandez-Martinez, F. Avecilla, C. Platas- Iglesias, A. de Blas, T. Rodríguez-Blas, Inorg. Chem. 44 (2005) 5428.

[29] D. Esteban-Gomez, C. Platas-Iglesias, A. de Blas, L. Fabbrizzi, T. Rodríguez-Blas, Chem. Eur. J. 14 (2008) 5829. 
[30] D. Esteban, D. Bañobre, R. Bastida, A. de Blas, A. Macías, A. Rodríguez, T. Rodríguez-Blas, D.E. Fenton, H. Adams, J. Mahía, Inorg. Chem. 38 (1999) 1937.

[31] C. Platas-Iglesias, D. Esteban, V. Ojea, F. Avecilla, A. de Blas, T. Rodríguez-Blas, Inorg. Chem. 42 (2003) 4299.

[32] N. Su, J.S. Bradshaw, X.X. Zhang, P.B. Savage, K.E. Krakowiak, R.M. Izatt, J. Heterocycl. Chem. 36 (1999) 771.

[33] W.C. Wolsey, J. Chem. Educ. 50 (1973) A335.

[34] WinGX 1.70.01, An integrated system of Windows programs for the solution, refinement and analysis of single crystal X-ray diffraction data L.J. Farrugia, J. Appl. Crystallogr. 32 (1999) 837.

[35] DIRDIF99 program system. P.T. Beurskens, G. Beurskens, R. de Gelder, S. Garcia-Granda, R.O. Gould, R. Israel and J.M.M. Smits, Crystallography Laboratory, University of Nijmegen, The Netherlands, 1999.

[36] G.M. Sheldrick, Acta Crystallogr., Sect. A64 (2008) 112.

[37] Superflip - a computer program for the solution of crystal structures by charge flipping in arbitrary dimensions. L. Palatinus, G. Chapuis, J. Appl. Crystallogr. 40 (2007) 786.

[38] A.D. Becke, J. Chem. Phys. 98 (1993) 5648.

[39] C. Lee, W. Yang, R.G. Parr, Phys. Rev. B 37 (1988) 785.

[40] GAUSSIAN 03, Revision C.01, M.J. Frisch, G.W. Trucks, H.B. Schlegel, G.E. Scuseria, M.A. Robb, J.R. Cheeseman, J.A. Montgomery, Jr., T. Vreven, K.N. Kudin, J.C. Burant, J.M. Millam, S.S. Iyengar, J. Tomasi, V. Barone, B. Mennucci, M. Cossi, G. Scalmani, N. Rega, G.A. Petersson, H. Nakatsuji, M. Hada, M. Ehara, K. Toyota, R. Fukuda, J. Hasegawa, M. Ishida, T. Nakajima, Y. Honda, O. Kitao, H. Nakai, M. Klene, X. Li, J.E. Knox, H.P. Hratchian, J.B. Cross, V. Bakken, C. Adamo, J. Jaramillo, R. Gomperts, R.E. Stratmann, O. Yazyev, A.J. Austin, R. Cammi, C. Pomelli, J.W. Ochterski, P.Y. Ayala, K. Morokuma, G.A. Voth, P. Salvador, J.J. Dannenberg, V.G. Zakrzewski, S. Dapprich, A.D. Daniels, M.C. Strain, O. Farkas, D.K. Malick, A.D. Rabuck, K. Raghavachari, J.B. Foresman, J.V. Ortiz, Q. Cui, A.G. Baboul, S. Clifford, J. Cioslowski, B.B. Stefanov, G. Liu, A. Liashenko, P. Piskorz, I. Komaromi, R.L. Martin, D.J. Fox, T. Keith, M.A. Al-Laham, C.Y. Peng, A. Nanayakkara, M. Challacombe, P.M.W. Gill, B. Johnson, W. Chen, M.W. Wong, C. Gonzalez, J.A. Pople, Gaussian, Inc., Wallingford CT, 2004.

[41] P.J. Hay, W.R. Wadt, J. Chem. Phys. 82 (1985) 270.

[42] P.J. Hay, W.R. Wadt, J. Chem. Phys. 82 (1985) 284.

[43] P.J. Hay, W.R. Wadt, J. Chem. Phys. 82 (1985) 299.

[44] K. Nakamoto, Infrared and Raman Spectra of Inorganic and Coordination Compounds, third ed., J. Wiley, New York, Chichester, Brisbane and Toronto, 1972, pp. 142-154.

[45] W.J. Geary, Coord. Chem. Rev. 7 (1971) 81.

[46] R.G. Pearson, R.J. Mawby, Halogen Chem. 3 (1967) 55.

[47] M.B. Duriska, S.M. Neville, S.R. Batten, Chem. Commun. (2009) 5579.

[48] J. Hu, L.J. Barbour, R. Ferdani, G.W. Gokel, J. Supramol. Chem. 1 (2001) 157. 
[49] J. Hu, L.J. Barbour, R. Ferdani, G.W. Gokel, Chem. Commun. (2002) 1806.

[50] A.S. De Sousa, R.D. Hancock, J.H. Reibenspies, J. Chem. Soc., Dalton Trans. (1997) 939.

[51] E.J. Corey, J.C. Bailar Jr., J. Am. Chem. Soc. 81 (1959) 2620.

[52] J.K. Beattie, Acc. Chem. Res. 4 (1971) 253.

[53] H.M. McConnell, J. Chem. Phys. 27 (1957) 226. 